\title{
Biomass production potentials in Central and Eastern Europe under different scenarios
}

\author{
J. van Dam ${ }^{\text {a }}$, A.P.C. Faaij, ${ }^{\mathrm{a}, *}$, I. Lewandowski ${ }^{\mathrm{a}}$, G. Fischer ${ }^{\mathrm{b}}$ \\ ${ }^{a}$ Copernicus Institute for Sustainable Development, Department of Science, Technology and Society, Utrecht University, Heidelberglaan 2 , \\ 3584 CS Utrecht, The Netherlands \\ ${ }^{\mathrm{b}}$ International Institute for Applied Systems Analysis (IIASA), A-2361 Laxenburg, Austria
}

Received 12 December 2005; received in revised form 4 October 2006; accepted 18 October 2006

\begin{abstract}
A methodology for the assessment of biomass potentials was developed and applied to Central and Eastern European countries (CEEC). Biomass resources considered are agricultural residues, forestry residues, and wood from surplus forest and biomass from energy crops. Only land that is not needed for food and feed production is considered as available for the production of energy crops. Five scenarios were built to depict the influences of different factors on biomass potentials and costs. Scenarios, with a domination of current level of agricultural production or ecological production systems, show the smallest biomass potentials of 2-5.7 EJ for all CEEC. Highest potentials can reach up to $11.7 \mathrm{EJ}$ ( $85 \%$ from energy crops, $12 \%$ from residues and $3 \%$ from surplus forest wood) when 44 million ha of agricultural land become available for energy crop production. This potential is, however, only realizable under high input production systems and most advanced production technology, best allocation of crop production over all CEEC and by choosing willow as energy crops. The production of lignocellulosic crops, and willow in particular, best combines high biomass production potentials and low biomass production costs. Production costs for willow biomass range from 1.6 to $8.0 € / \mathrm{GJ}$ HHV in the scenario with the highest agricultural productivity and $1.0-4.5 € / G J ~ H H V$ in the scenario reflecting the current status of agricultural production. Generally the highest biomass production costs are experienced when ecological agriculture is prevailing and on land with lower quality. In most CEEC, the production potentials are larger than the current energy use in the more favourable scenarios. Bulk of the biomass potential can be produced at costs lower than $2 € /$ GJ. High potentials combined with the low cost levels gives CEEC major export opportunities.
\end{abstract}

(C) 2007 Elsevier Ltd. All rights reserved.

Keywords: Biomass potential; Biomass cost-supply curves; Central and Eastern European countries (CEEC)

\section{Introduction}

Nearly two-thirds of renewable energy sources (RES) in the European Union (EU) stem from biomass, including wastes [1]. For the near future, increasing biomass use is considered to be essential in meeting the targets set out by

Abbreviations: CEEC, Central and Eastern European Countries; WEC, Western European countries; CAP, Common Agricultural Policy; NUTS, Nomenclature of Territorial Units for Statistics; DG, Directorate General; EU, European Union; GMO, genetically modified organisms; VS, very suitable land; S, suitable land; MS, moderately suitable land; mMs, marginally suitable land; NS, not suitable land; dm, dry matter; RES, renewable energy sources

*Corresponding author. Tel.: + 31 203537643; fax: + 31302537601

E-mail address: a.faaij@chem.uu.nl (A.P.C. Faaij). the EU [2]. Beside this, biomass can-unlike wind or hydropower-be used as RES in the transport sector. Biomass sources are wastes, energy crops, agricultural residues or residues from forests. The utilization of energy crops in the near future is uncertain, but in the longer term potentially the largest contributor to bio-energy production. As the potential from residues and wastes is already utilized to a high degree in the EU, a further growth in biomass production should come from energy crops [3]. Since June 2003, the growing of crops as renewable energy is encouraged in the Common Agricultural Policy (CAP) reforms by promoting the use of energy crops on fallow land and in the form of subsidies [4].

A large increase in energy crop production requires large land areas in the EU. However, the resources of good 
quality land area is limited and the production of bio-fuels will compete with food production and demands from the forest industry as well as from environmental protection and conservation considerations. Furthermore, an extension of bio-fuel production will only occur when their prices can compete with those of fossil fuels. Low costs for bio-fuel options are therefore needed in the future.

At the same time, the ongoing expansion of the EU and the inclusion of the Central and Eastern European Countries (CEEC) in agricultural and energy EU policies create potential. Agriculture plays - and is expected to play in the mid term - an important role in the CEEC [5]. Beside this, the share of employment in the agricultural sector is still large [5].

In future, ongoing rationalization of agriculture in the CEEC is expected. This will lead to increased productivity and economic performance. On the other hand, unemployment and an increase in abandoned land are expected as well. This can put high pressure on the socio-economic developments in rural areas in the CEEC. Several countries in the CEEC region are characterized by large land resources, comparatively low labour and agricultural production costs and relatively low productivity compared to Western European countries (WEC) (see e.g. [6,7]). Using potential surplus land in the CEEC for biomass production could provide economically interesting biomass supplies and in the same time offer an alternative economic activity to rural regions affected by changes in agriculture. Whether this concept is feasible and to what extent such targets could be obtained by trading bio-fuels between Eastern and Western Europe, has never been investigated.

Several national institutes and universities or other European (inter-) national organizations have already studied bio-energy potentials and supply and demand of bio-energy in the CEEC countries $[1,8-13]$. These studies, however, only give a rough picture of the possible bioenergy potential in these countries and do not address potential land-use changes over time. Therefore, these studies do not allow for an adequate and comprehensive research on the possibilities of trading bio-fuels from CEEC to WEC. Most of the studies are based on country statistics for agriculture and forestry and give limited information about the methodology used. A unified methodology is, however, required for a good analysis of the biomass potential results to make comparisons between countries and regions in the CEEC possible. Apart from $[1,13]$ most studies are performed on a national level. In reality, there will be differences in cost levels, productivity and availability of land between the regions within the CEEC. A regional biomass assessment-instead of a study on a country level-is therefore needed to identify the differences at this level of detail. Most studies give no or little attention to energy crop production in the CEEC. The reason given in the studies is that energy crop production is considered as not feasible or too expensive at this moment. However, this can change in a short time when EU countries need to fulfil the targets of the EC Biofuels Directive (which sets as reference values a $2 \%$ market share for bio-fuels in 2005 and $5.75 \%$ share in 2010) [64] and with increasing prices for fossil fuels. It is also known that such crops can represent a much larger potential than residues and forest wood $[14,15]$. Therefore, energy crop production should be included in the biomass potential assessment. Only the studies $[1,13]$ relate the biomass potential with the land use in the CEEC. However, these studies do not take into account that production and demand of food products have their influence on the size of the agricultural area available: a change in food demand (i.e. cereal demand) is important as it influences the land area required for food production. Changes in production and demand should thus be included when assessing land use patterns in a country.

Policies on demand for food and energy change over time; this has a large impact on available biomass as well. An important requirement for a secure long-term trade of biomass resources from CEEC to WEC is the certainty that sufficient resources are available in the long term for a constant supply. Therefore, the biomass potential assessment should not only look at the present situation but should also include future trends by the use of scenario analysis. Only the Czech [10] and Hungarian [9] studies show some trends in supply and demand of biomass resources to 2010. The other studies focus on the present situation in the CEEC.

Finally, no studies, including the studies from the studies $[1,13]$, combine cost levels with a biomass potential study. However, this is - as also mentioned by [16] - an important barrier (or driver) for further development of biomass production. Cost relations should therefore be included in the analysis as the biomass production as trade will only be feasible when this concept is profitable for the stakeholders in the CEEC.

The conclusion from above is that a unified methodology is missing to compare the results of the biomass potential assessment for the CEEC on a regional, national and international level. Another problem is the lack of attention to land use, policy and demand changes over time, which can be included in scenarios. There has been only limited research on the costs and prices of biomass, although this is and can be an important barrier in the development of biomass production in the CEEC.

A key question in this study is whether the bio-energy potential in the CEEC is indeed large enough to supply bio-fuels to the European market and under what conditions such potentials can be developed. The aim of this study is therefore to implement a biomass potential assessment on a regional level for the CEEC, which is based on scenarios, so that land use changes over time are included in the analysis and impacts of policy choices can be assessed. As cost levels for biomass production need to be included in the analysis, final deliverables are the cost-supply curves from different sources (energy crops, 
residues) under different production systems for the CEEC in relation to the scenario conditions. ${ }^{1}$

\section{Methodology}

The regional biomass potential assessment is implemented for the CEEC Estonia, Lithuania, Latvia, Poland, Romania, Bulgaria, Hungary, Czech Republic and Slovakia.

This study uses a standardized methodology to assess the biomass potential of the CEEC. The methodology is based on the study from Smeets et al. [15], which is a bottom-up approach to assess the global biomass potential on a country-to-country basis. The methodology from [15] is applied on a so-called Nuts-3 region level (see Fig. 1). NUTS stand for "Nomenclature of Territorial Units for Statistics "and are the statistical regions of Europe and the Accession Countries [17]. Nuts-3 regions are regional or district levels within a country [17].

A general overview of the methodology of the regional biomass potential assessment is given in Fig. 2. The total available biomass potential in a Nuts-3 region is the sum of biomass from energy crops, wood from surplus production forest, agricultural and forest residues.

The regional biomass potential assessment is based on land use changes over time for a set of scenarios. A scenario, with a defined set of parameters, requires a certain demand for food and forest products. A certain area of agricultural land and forestland will be needed to meet this demand. The size of this area will depend on (1) demand and (2) the defined production system (productivity) (Fig. 2). The current land minus the required future land for crop, livestock and wood production gives the possible surplus available land for biomass production, which can be used for energy crop cultivation. The amount of biomass from energy crops is calculated by multiplying the available land for the energy crop with the productivity data for energy crops. The available land for the energy crop depends on three different factors $[14,15,18]$ :

- Demand for food and forest products: only surplus land that is not needed to fulfil the food and wood demand is available for the production of energy crops (see Section 2.1).

- The productivity of the selected agricultural production system (see Section 2.2).

- Allocation procedures defining which land quality is used for each crop and the extent and geographic scope (i.e. regional, country level or beyond) considered to which land use patterns are allowed to change (see Section 2.3).

Table 1 gives an overview of data sources in this study.

\footnotetext{
${ }^{1}$ This biomass potential assessment is done in the framework of the project VIEWLS Clear VIEWS on Clean Fuels (NNES-2001-619), which was financed by EC DG-TREN. Background papers are available.
}

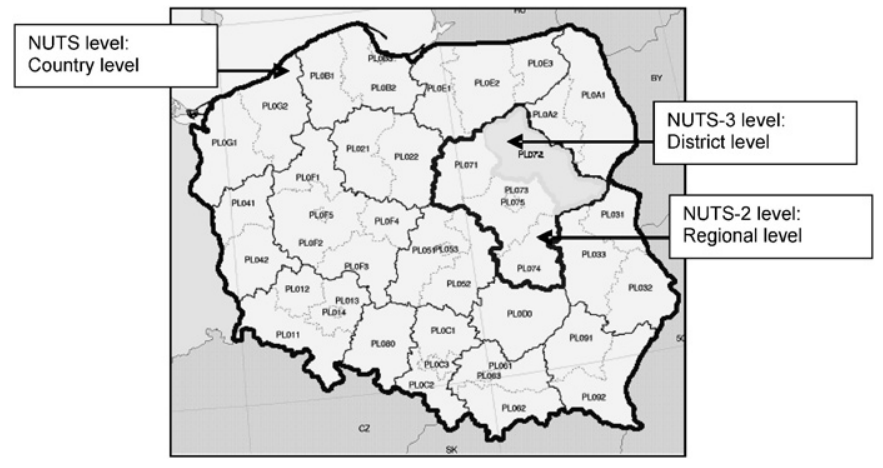

Fig. 1. Map of Poland showing Nuts-1, -2 and -3 regions. Nuts-3 regions are the level of detail for the biomass potential assessment in the CEEC in this study.

\subsection{Food demand and demand for forest products}

The food demand is calculated as the sum of domestic utilization, import and export rate. The domestic utilization of food in a country is largely influenced by population growth and GDP. The FAO projections [24] form the basis for this calculation of the estimated required food production in the CEEC countries. The projections for required food production and demand (crop and meat products) are available for the years 1997-1999, 2015 and 2030. FAO projections were used because they are developed for the long term (to 2030), are available on country level and provide a consistent database for all CEEC. These parameters are adapted for the set of defined scenarios (see Table 3) if assumptions differ largely from the assumptions of the FAO projections.

The required amount of forest products is related to the domestic consumption of forest products, import and export in a country. The consumption of forest products is strongly related to the growth of GDP in a country. Information about the amount of required forest products (sawn wood, wood based panels and paper board) is related to the amount of required round wood that is needed to produce these forest products. In this study the EFSOS scenarios $[25,27]$ are translated to the set of five developed VIEWLS scenarios that are used in this regional biomass potential assessment.

\subsection{Productivity}

The level of productivity in forest, livestock or crop production is one of the main parameters in the scenarios for the regional biomass potential assessment. An important factor for the level of productivity is the selected production system, which is characterized by its management practices. We will discuss these characteristics for crop, livestock and forest in the following sections.

\subsubsection{Livestock productivity: feed conversion efficiency}

The feed conversion efficiency (FCE) (tonne feed/tonne meat) is an indicator for the productivity level of a 


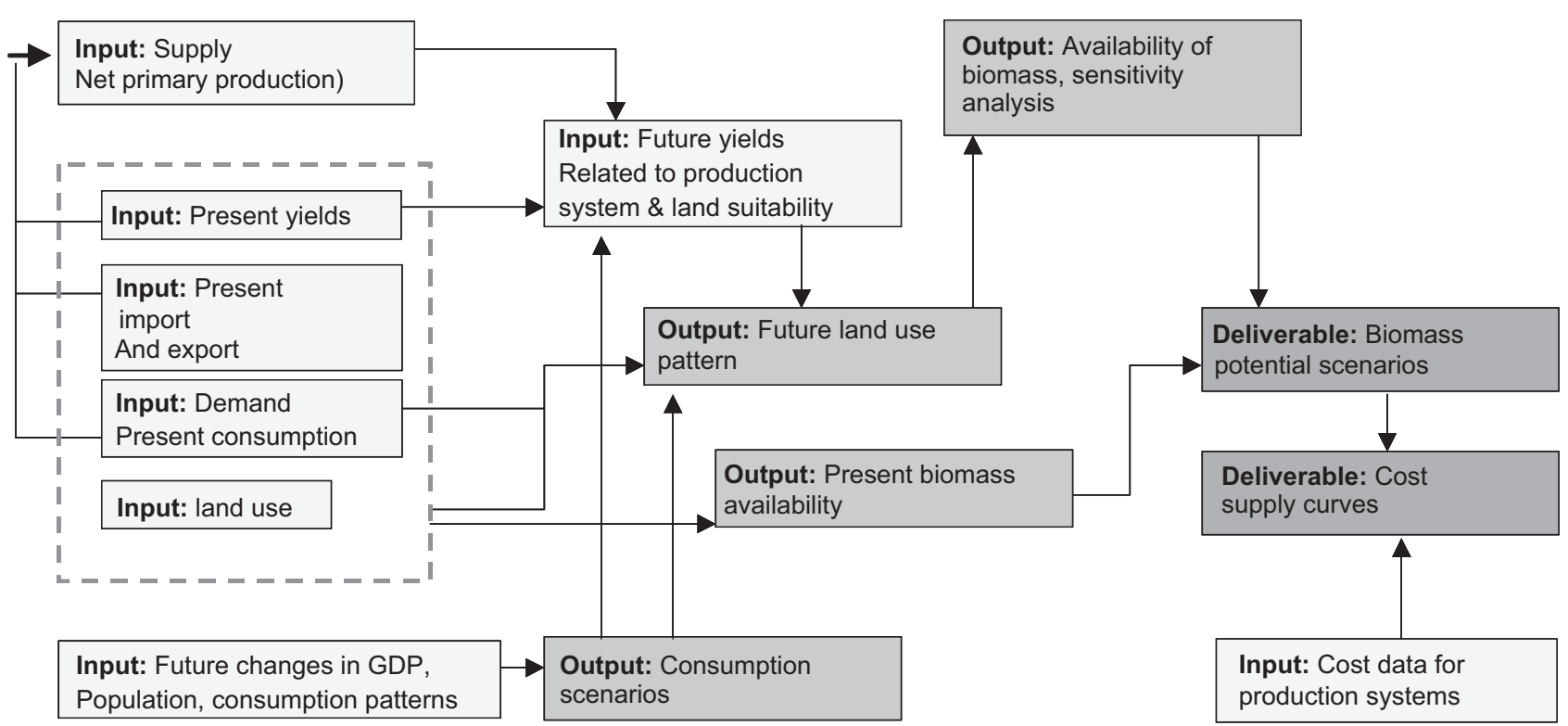

Fig. 2. General overview of the main components of the methodology for the biomass potential assessment.

livestock production system. Meat production divided by the FCE gives the required animal feed that is needed to perform the calculated livestock production. Livestock production systems differ in their production process. FCE levels are higher for pork and poultry compared to beef or sheep production. Livestock production systems require considerable amounts of animal feed, consisting of food crops, crop residues and crop by-products, fodder crops and grass. Increases in the FCE have an impact on the required crop production in a region because less feed production is required for the same amount of meat production. Furthermore, a more intensive livestock production system in general requires more concentrated feeds (protein content) and feed grains.

Not many data are available about FCE levels in the CEEC. Besides this, livestock productivity data are expressed in various units. Therefore, different sources were used to receive livestock productivity information (see Table 1). In the IMAGE model [30], the FCE leads for all scenarios to the same end-value in 2090, which we assume to be the most efficient FCE that can be achieved. The only difference between the scenarios is in which year this most efficient FCE is achieved. Based on the data from RIVM [30] and Bouwman et al. [29] we have defined different levels of FCE on country level for the livestock production systems belonging to the VIEWLS scenarios. FCE levels are related to different feed fractions per scenario.

\subsubsection{Productivity of agricultural crops: yield levels}

The productivity of crops is determined by the agricultural production system and the land suitability on a Nuts3 region level. The land suitability for a crop is determined by rainfall, temperature, soil quality and slope. Land suitability for a crop can have a strong variation in a geographical area. The production system is determined by management practices including the level of inputs, kind of machinery and technology used. For the regional biomass potential assessment we have developed an approach that enables us to show both the impact of the production system as well as the variation of land suitability classes on agricultural productivity levels in a region. Per production system (described below), we have developed a database with information about the area of suitable land and the related productivity levels per crop (see also Fig. 3). The land suitability classification per crop is based on the agroecological zone (AEZ) methodology from Fischer et al. [56] and contains five different land suitability classes: very suitable land (VS), suitable land (S), moderately suitable land (MS), marginally suitable land (mMs) and not suitable land (NS).

The data from IIASA [31] provide potential productivity data and land suitability data for a range of selected crops (see Table 1) for the high input (HI) rain-fed production system. The potential productivity is the productivity potentially achievable in a grid cell without management limitations [56]. The data are given in grid cells from $50 \times 50 \mathrm{~km}$. Each grid cell is linked to a grid cell number and a country number in an Excel database. As the selected level of detail in the model is the Nuts-3 region, grid cell data were converted to a Nuts-3 region level by estimating for each grid cell for which percentage it was situated in a selected Nuts-3 region. Data were not provided for all crops [31], yield and land suitability data for the other crops are derived from data sources listed in Table 1. This database is used as a basis to derive yield levels and land suitability data corresponding to other agricultural production systems than the HI rain-fed production system. Table 2 describes the mean features of the various production systems used here in different scenarios (see also Table 3 in Section 3). The following sections describe in more detail these production systems and how the yield levels for these production systems were derived. 
Table 1

Data sources used for the regional biomass potential assessment

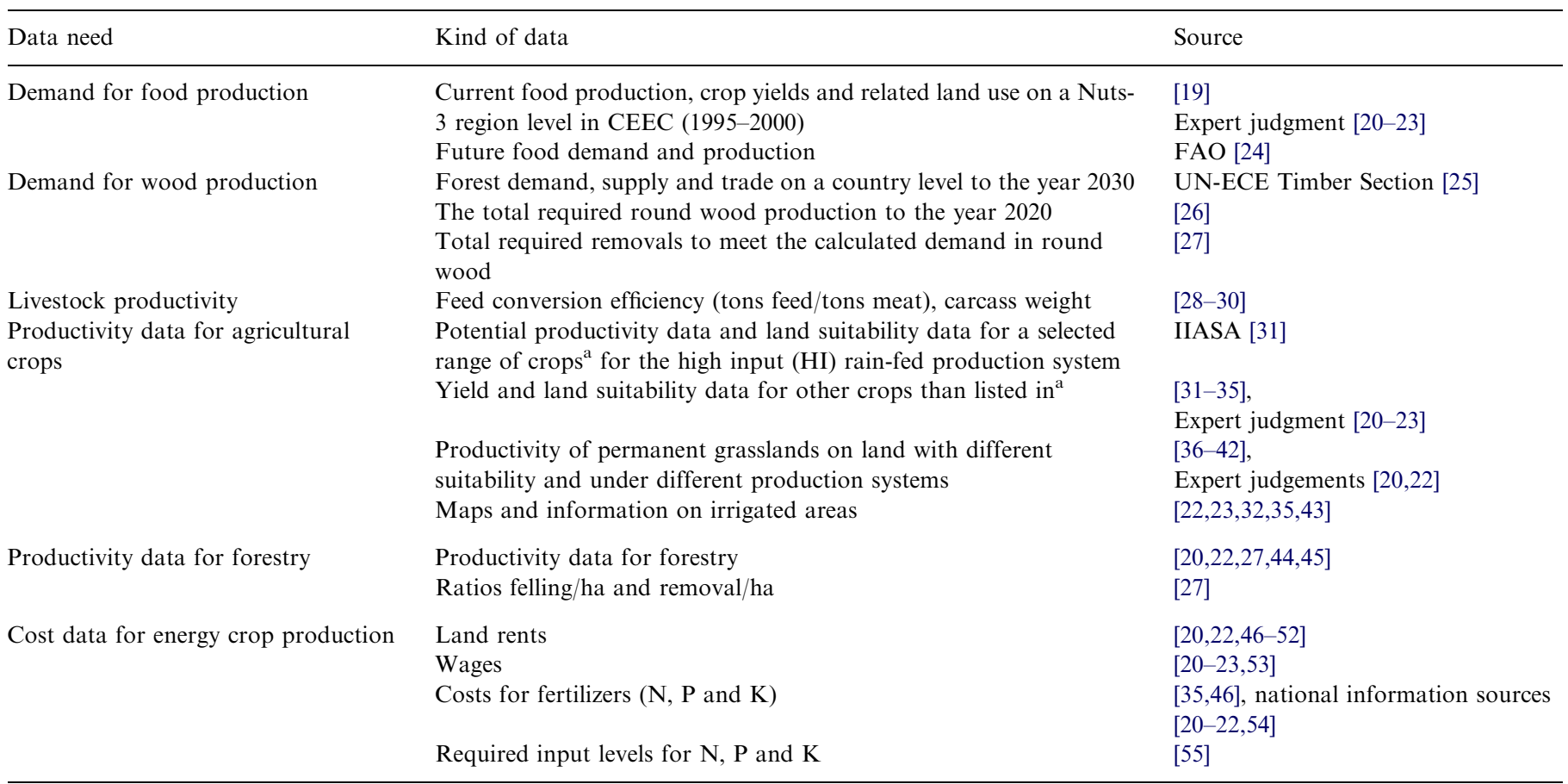

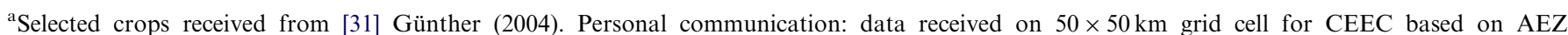
methodology are: wheat, grain maize, potato, sugar beet, rapeseed, sunflower, "other cereals", "total cereals", silage maize, willow, poplar, miscanthus.

2.2.2.1. Current agricultural production system. The 'current agricultural production system' reflects the currently practiced agricultural management system in the CEEC. Average current yield levels are available from EUROSTAT [19] on a Nuts-3 region level. Further subdivisions of these yield levels to land suitability classes is not available from EUROSTAT [19], neither the dataset on land availability related to this production system. Therefore, the statistical yield data are compared with the calculated average yield levels, on data from Fischer [31] and IIASA [32], available for different agricultural production systems and land suitability classes. For the development of the dataset on the amount of available land for the 'current agricultural production system', the dataset from the production system is used, developed from Fischer [31] and IIASA [32], of which the yield levels where most comparable with the yield levels from the EUROSTAT [19] dataset. In practice, in most cases the low to intermediary intensity management system was used. For the development of a dataset of the yield levels for the 'current agricultural production system', the ratio between the average yield levels is calculated from [19,31,32] for the selected agricultural production system ([average yield level statistics: average calculated yield level] [yield level specific land suitability class]) and this ratio is used for the development of the yield levels for the different land suitability classes.

2.2.2.2. Ecological production system. The basic concept of the 'ecological production system' is that environmental risks or damages should be avoided. FAO [57] mentions that yield levels drop by $10-30 \%$ when high external input systems are converted to organic management. Yields do, however, not always fall when conversion starts from traditional low-input systems [57]. Yield levels and land suitability data provided by IIASA [32] for intermediate and low input production system are used here as reference data for the ecological production system. Although yield levels and land suitability data based on the intermediate production system are used for the ecological production system, it must be kept in mind that the level of technology and management is very high for this production system. Thus, the assumptions for the performance of the ecological production system are different from those of the intermediate production system.

2.2.2.3. High input production system. In the 'high input production system' intensive farming is performed and optimal management practices are applied. High inputs are used to achieve maximum yields. The yield levels and land suitability data provided by Fischer [31] on a grid cell level are provided for a selective number of crops. The data for AEZ from IIASA [32] provide yield levels and land suitability data on a country level for the intermediate and low input production system for a wider range of crops. To make a comparison between the high input and low/intermediate input production systems possible for a larger array of crops, IIASA [32] data on country level are used to estimate the percentage of change in yield levels 


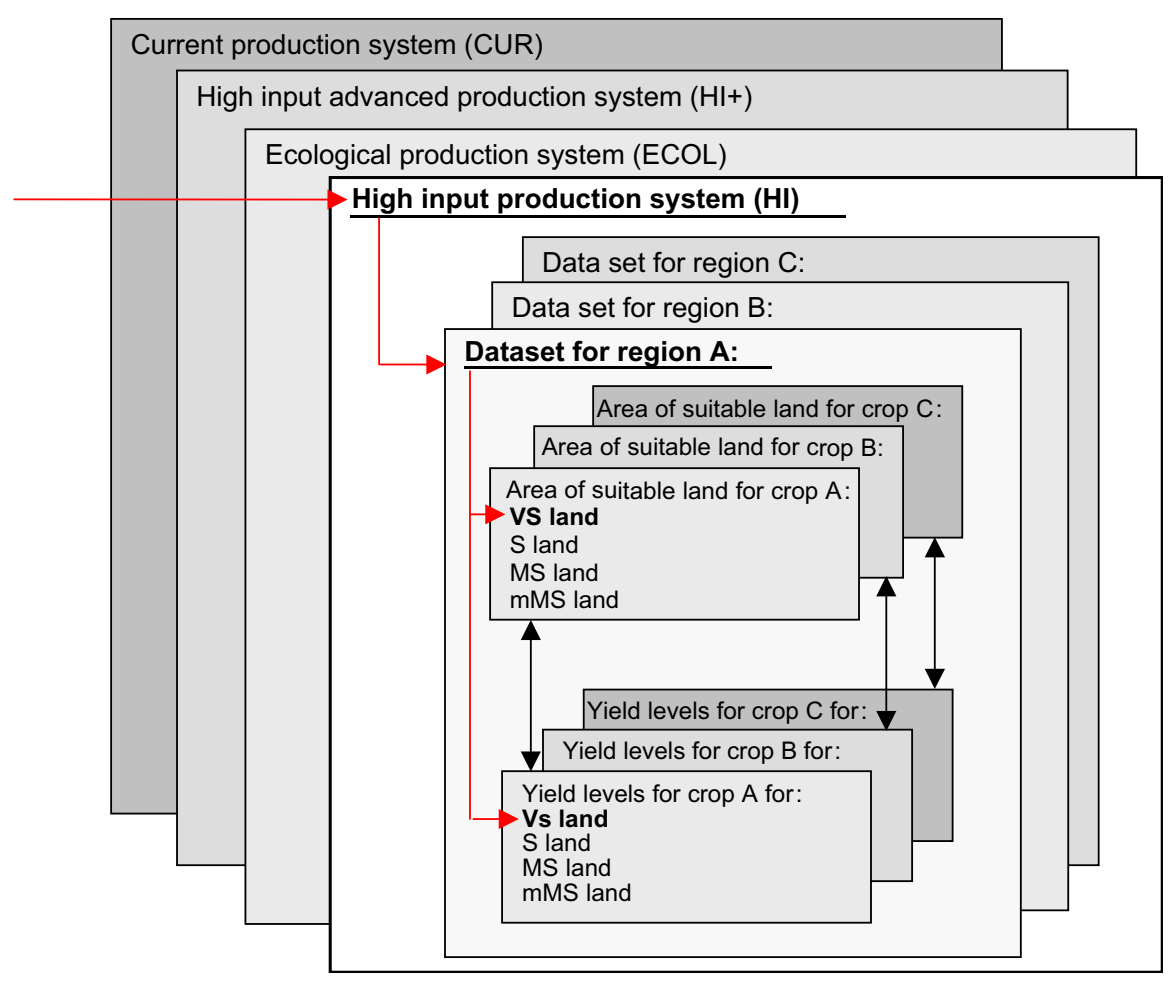

Fig. 3. Systematic overview of database in the VIEWLS model for land suitability and productivity data per crop for all Nuts-3 regions in the CEEC, for a set of defined agricultural production systems.

Table 2

Main features of the production systems used in the different scenarios

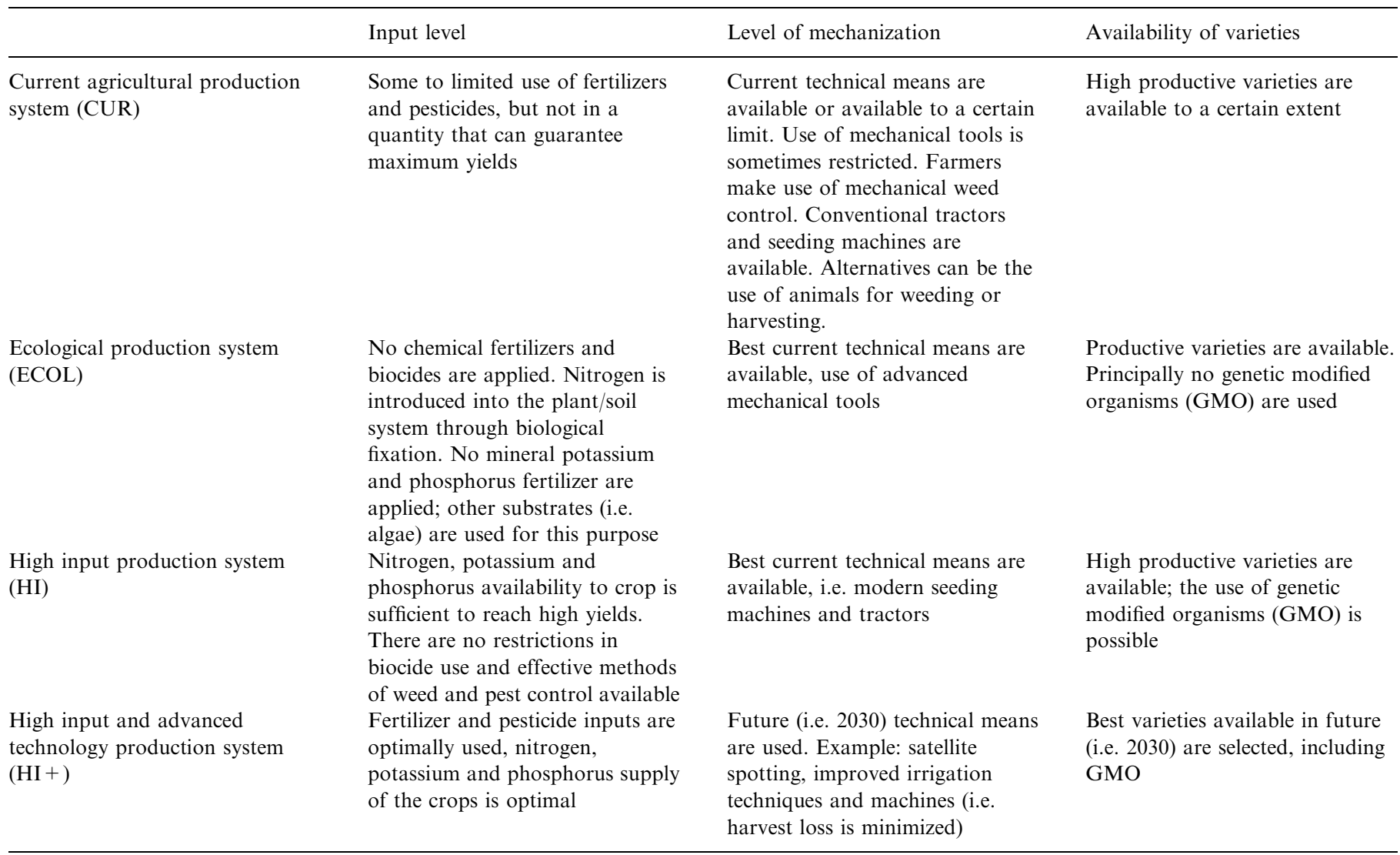


and land suitability areas between the different production systems for these crops which are not covered by the database from Fischer [31]. This percentage of change on country level is used to convert the Nuts-3 region database for the high input rain-fed production system to a database for the low input and intermediate production system.

\subsubsection{High input and advanced technology production} system. In the 'high input and advanced technology production system' very high quality standards and advanced management practices are applied. The increase in yields in the past decades has been the result of a combination of factors such as better crop varieties, availability of cheap and improved fertilizer and herbicides and better irrigation techniques. Yield developments [35] over the past $30 \mathrm{yr}$ for cereals, root and tuber crops in Europe (EU12) and the US show that yields have doubled in $30 \mathrm{yr}$. Taking into consideration that large improvements in this period are achieved due to availability of fertilizers, pesticides and irrigation (the so called "Green Revolution"), a yield increase of $30 \%$ for the $\mathrm{HI}+$ system compared to the high input system or a yield increase of about $1 \%$ per year is assumed. Land suitability areas are similar to those of the HI production system.

It is assumed that a farmer is able to change in a short time period from a low to intermediate or high input management system on condition that consultancy and money is available for him at that moment. The change from a high input to a high advanced management system is a more gradual development, as main stimulations for this change are technical developments and research over time.

Irrigation is practised on a large scale in CEEC, especially in the more southern countries. Therefore, it is realistic to include the practise of irrigation in the agricultural production systems. There are no sources available that provide information about the size of irrigated areas on a Nuts-3 region level. Therefore a calculation was carried out, based on information available for rain-fed production systems by using different data sources (see Table 1). The global map of irrigated areas [43] was enlarged to the scale of Europe and individual Eastern European Countries and, after indicating the location of the Nuts-3 regions into these country maps; the percentage of irrigated area per Nuts-3 region was estimated. IIASA [32] provides information about land suitability and yield levels for a high input and intermediate irrigated production system on country level for the CEEC. These data provide information about: (1) the impact of irrigation on the size of the area of suitable land available for a crop, (2) the possibility for irrigation in a region, and (3) the impact of irrigation on yields. Data from [22,35,23] were used as background information.

\subsubsection{Forest productivity}

The total required round wood is translated into the total required removals on country level for different scenarios. The total removals are defined as "the volume of all trees, living or dead, that are felled and removed from the forest, other wooded land or other felling sites" [27]. The databases and publications $[27,44,45]$ provide a relevant database on forest production in Europe. As the methodology behind the data collection is consistent for all CEEC, this database was used as starting point for forest productivity data. The ratios of felling per ha and removal per ha can be used as indicators for forest productivity. These data are given by Schelhaas et al. [27] on country level for the base scenario (as described in [27]) and are translated into the scenarios used in our model.

The agricultural model is fed with output from the forest model. That means in case extra land is required to meet wood production, this land is subtracted from the total available suitable land for all crops.

\subsection{Allocation procedures}

Basically, the allocation procedure has three main steps, which influence the results on available land for energy crop production. The first step reserves for some scenarios a certain amount of land is reserved for extra growth in urban areas, forest areas or for energy crop production (see Table 3). This reserved land is subtracted from the total available suitable land for all crops. The remaining total available suitable land for all crops, which is different per scenario, is used for further allocation in the procedure. A second input in the database is the amount of suitable land per individual crop and their related yield levels, which is also differentiated per scenario.

The total required food production and the required production per crop, combined with the data about yield levels on available suitable land, serve as the starting points for the further allocation procedure. The next step is the distribution of the required food production over the available land in a region $\mathrm{X}$. An allocation choice here is the selection of the geographical size of region $\mathrm{X}$. It is possible to allocate the required food production on country level, CEEC level or over a smaller region, which has its impact on the efficiency level of food production in a region.

The next step is explained by the example of the allocation procedure for (very suitable) VS land. In the model, the required production is distributed over the VS land for all crops individually. As the total area of VS land needs to be distributed over a wide range of crops, this procedure takes place in six allocation steps per land suitability type. There are 24 allocation steps in the model to come to the final result, which is the available land for energy crop production in a region. The methodology of this allocation procedure is explained in more detail in [15]. However, it must be considered that both, the yield levels and the amount of available land for each individual crop and for all crops in total, is different for each defined agricultural management system, which has also its impact on the results coming from the allocation procedure. 


\subsection{Cost-supply curves}

The technical biomass potential is translated into economic potentials by estimating the production costs based on the level of technology and the selected agricultural production system applied to produce the bio-energy. Production costs for biomass are collected for different land suitability types and production systems. Final deliverable are the cost-supply curves. Fig. 4 shows an example of the procedure to calculate production costs of bio-energy. As Fig. 4 shows, the production costs are divided in two different variables:

- Fixed costs: the costs are independent from production levels in the short run.

- Operational costs: the costs are dependent from production levels in the short run.

For this study, every Nuts-3 region contains a dataset of cost variables for different production systems, subdivided to different land suitability classes, both for the present situation and for the future selected scenario. The implementation of this approach requires sufficient cost data in a region or country.

The methodology requires for each selected energy crop a database on the costs of various production factors such as pesticides, fertilizers, labour, fuels, land, depreciation of machinery, etc. Table 1 shows the sources for the different cost data used here. This database is compiled in this project based on data of energy crop production in the CEEC (see Table 1 for references) and projections concerning future developments of costs, yields and developments.

\section{Scenarios}

The scenarios used for the regional biomass potential assessment characterize the main current and future drivers in Europe related to agriculture and land use. These drivers are translated into quantitative parameters (for example level of trade, management practice, labour and land costs, level of self-sufficiency, yield levels, etc.). These parameters are used in the analysis of the regional biomass potential assessment. The time frame considered is 2030. The following set of scenarios is defined:

V1 scenario: There is a liberalization of trade; no market barriers exist between the EU and the world market for agricultural products. EU specializes in products, which are competitive on the world market. There is a strong increase in import and export flows. There is a strong rationalization of agriculture and adoption of the most efficient management practices.

V2 scenario: Policies are regionally orientated. There is an uneven economic development in Europe. Trade barriers exist between the Western and Eastern European market. The agriculture in CEEC has difficulties to compete with agriculture in WEC.

V3 scenario: There are no internal trade barriers in Europe. CEEC have completely adapted the EU legislation and can compete fully with WEC agriculture. CAP regulates agriculture in Europe. CAP reforms (i.e. reduction of support levels in agriculture compared to current levels) in Europe are in full implementation.

V4 scenario: There are no internal trade barriers within Europe. Europe protects its own internal market strongly. EU strives for self-sufficiency in its own food and energy need. Internal trade has increased. External trade of products on the world market is limited.

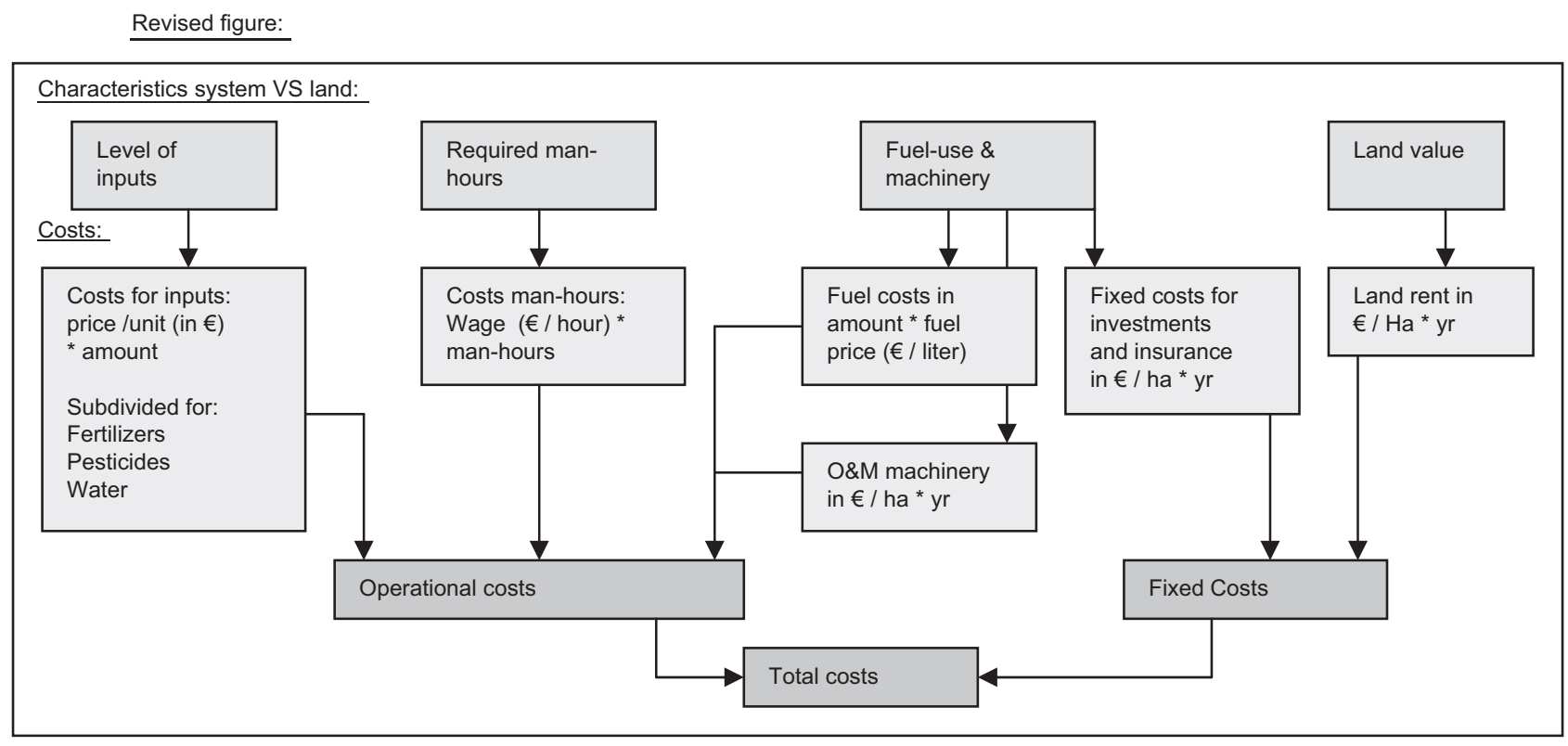

Fig. 4. Methodology and data requirement for the calculation of biomass production costs, related to results of biomass potential assessment. Example shows the costs requirements for bio-energy production with production system X on VS land. 
Table 3

Main indicators for scenario analysis in the regional biomass potential assessment of CEEC

\begin{tabular}{|c|c|c|c|c|c|}
\hline \multirow[t]{2}{*}{ Indicators } & \multicolumn{5}{|l|}{ Scenarios } \\
\hline & V1 & $\mathrm{V} 2$ & V3 & V4 & V5 \\
\hline Food consumption & $\begin{array}{l}\text { Based on FAO } \\
\text { projections, increase } \\
\text { in meat consumption }\end{array}$ & $\begin{array}{l}\text { Based on FAO } \\
\text { projections, decrease } \\
\text { in meat consumption }\end{array}$ & $\begin{array}{l}\text { Based on FAO } \\
\text { projections }\end{array}$ & $\begin{array}{l}\text { Based on FAO } \\
\text { projections }\end{array}$ & $\begin{array}{l}\text { Based on FAO } \\
\text { projections, decrease } \\
\text { in waste from food }\end{array}$ \\
\hline Food trade & $\begin{array}{l}\text { Products that can be } \\
\text { produced cheaper } \\
\text { elsewhere in the } \\
\text { world are imported } \\
\text { into Europe }\end{array}$ & $\begin{array}{l}\text { Conform current } \\
\text { situation in CEEC }\end{array}$ & $\begin{array}{l}\text { CAP reforms are } \\
\text { implemented }\end{array}$ & $\begin{array}{l}\text { Import is reduced. } \\
\text { Domestic products } \\
\text { replace products with } \\
\text { high import rates in } \\
\text { Europe }\end{array}$ & $\begin{array}{l}\text { CAP reforms are } \\
\text { implemented }\end{array}$ \\
\hline $\begin{array}{l}\text { Livestock production } \\
\text { system }\end{array}$ & $\begin{array}{l}\text { High-tech advanced, } \\
30 \% \text { higher share of } \\
\text { fodder from feed } \\
\text { crops }\end{array}$ & $\begin{array}{l}\text { Current efficiency } \\
\text { levels }\end{array}$ & $\begin{array}{l}\text { High input } \\
\text { management system, } \\
15 \% \text { higher share of } \\
\text { fodder from feed } \\
\text { crops }\end{array}$ & $\begin{array}{l}\text { High-tech advanced, } \\
30 \% \text { higher share of } \\
\text { fodder from feed } \\
\text { crops }\end{array}$ & $\begin{array}{l}\text { Underlying } \\
\text { assumption is } \\
20-30 \% \text { organic } \\
\text { agriculture, based on } \\
\text { FAO projections }\end{array}$ \\
\hline $\begin{array}{l}\text { Agricultural } \\
\text { production system }\end{array}$ & $\begin{array}{l}\text { High input and } \\
\text { advanced technology } \\
\text { production system }\end{array}$ & $\begin{array}{l}\text { Current agricultural } \\
\text { production system }\end{array}$ & $\begin{array}{l}\text { High input } \\
\text { production system } \\
\text { (current state of the } \\
\text { art in Western } \\
\text { Europe) }\end{array}$ & $\begin{array}{l}\text { High input and } \\
\text { advanced technology } \\
\text { production system }\end{array}$ & $\begin{array}{l}\text { Ecological } \\
\text { production system }\end{array}$ \\
\hline $\begin{array}{l}\text { Reservation of land } \\
\text { in allocation } \\
\text { procedure }^{\mathrm{a}}\end{array}$ & $\begin{array}{l}1 \% \text { land reserved for } \\
\text { urban areas }\end{array}$ & - & $\begin{array}{l}2 \% \text { of agricultural } \\
\text { land reserved for set- } \\
\text { aside land which can } \\
\text { be used for energy } \\
\text { crop production }\end{array}$ & $\begin{array}{l}1 \% \text { land reserved for } \\
\text { urban areas }\end{array}$ & - \\
\hline $\begin{array}{l}\text { Allocation: } \\
\text { geographical scale }\end{array}$ & $\begin{array}{l}\text { Required food } \\
\text { production is } \\
\text { allocated over the } \\
\text { CEEC }\end{array}$ & $\begin{array}{l}\text { Required food } \\
\text { production is } \\
\text { allocated on country } \\
\text { level }\end{array}$ & $\begin{array}{l}\text { Required food } \\
\text { production is } \\
\text { allocated on country } \\
\text { level }\end{array}$ & $\begin{array}{l}\text { Required food } \\
\text { production is } \\
\text { allocated on Nuts-2 } \\
\text { region level }\end{array}$ & $\begin{array}{l}\text { Required food } \\
\text { production is } \\
\text { allocated on country } \\
\text { level }\end{array}$ \\
\hline Land rents & $\begin{array}{l}\text { International open } \\
\text { market, no subsidies, } \\
\text { land rents are } \\
\text { remarkably lower } \\
\text { than current average } \\
\text { EU-15 }\end{array}$ & $\begin{array}{l}\text { Current CEEC cost } \\
\text { levels for land rents }\end{array}$ & $\begin{array}{l}\text { Land rents are lower } \\
\text { than current average } \\
\text { EU level due to CAP } \\
\text { measurements }\end{array}$ & $\begin{array}{l}\text { Land rents are } \\
\text { comparable to } \\
\text { current land rents in } \\
\text { France }\end{array}$ & $\begin{array}{l}\text { Competition in land } \\
\text { increases. Land rents } \\
\text { are comparable to } \\
\text { current land rents in } \\
\text { EU-15 }\end{array}$ \\
\hline Labour costs & $\begin{array}{l}\text { Increase in wages due } \\
\text { to strong economy } \\
\text { and high level of } \\
\text { technological } \\
\text { developments }\end{array}$ & $\begin{array}{l}\text { Current wages in } \\
\text { CEEC }\end{array}$ & $\begin{array}{l}\text { Average EU labour } \\
\text { costs }\end{array}$ & $\begin{array}{l}\text { Increase in wages due } \\
\text { to strong economy } \\
\text { and high level of } \\
\text { technological } \\
\text { developments }\end{array}$ & $\begin{array}{l}\text { Average EU labour } \\
\text { costs }\end{array}$ \\
\hline
\end{tabular}

Depending on the scenario, a certain percentage of land is reserved for future land use planning.

V5 scenario: EU has a priority for sustainable development and nature conservation. Biodiversity, protection of rural areas and maintenance of the vitality of forest and grassland areas has a high concern. There is a tendency of greening of agriculture. A certain level of protection (trade barriers) is needed.

Table 3 gives an overview of the most relevant indicators used in the scenario analysis. The indicators refer to the main variables mentioned by $[15,18,14]$ that have an impact on cost levels and final biomass potential in a region, in specific derived from energy crop production.

\section{Results of biomass potential assessment in CEEC}

Basically, there are three types of results from the biomass potential assessment in the CEEC, which will be shown in the following order:

- The availability of land for energy crop production in the CEEC.

- The biomass potential in the CEEC.

- The cost-supply curves.

The results are produced on a Nuts-3 level for eight selected energy crops (for selection of energy crops see [58]). Here, the results for the whole CEEC region are presented, combined with illustrations of specific results by the example of Poland.

\subsection{Available land for energy crop production in CEEC}

The amount of available land for energy crop production results from the allocation procedure that distributes the 
required food production over the available suitable land for food production. Fig. 5 shows the results of available land for energy crop production for the set of scenarios (described in Section 3) on a country level. The results show that under the V1, V3 and V4 scenario there is generally most land available for energy crop production. There is not only a differentiation in the quantity of available land for energy crop production per scenario, but also in the quality of land that is available. This is for example shown in Fig. 5 for Poland. Here marginally suitable land appears under the scenarios V2 and V5, but almost disappears under the scenarios V1, V3 and V4. For some scenarios (mainly with an intensive production system) more land can be considered as available for energy crop production if a production system, which is less extensive than defined under the scenario, is performed on this land. This is mainly the case for the Northern European countries where irrigation plays a marginal role in agriculture. To reflect this extra available land, the land class "extensive land" is introduced in Fig. 5. This is land that is available for energy crop production if managed under an extensive production system. The main underlying factors that determine the results of available land for energy crop production are the area required for food and fodder production, the allocation procedure and the

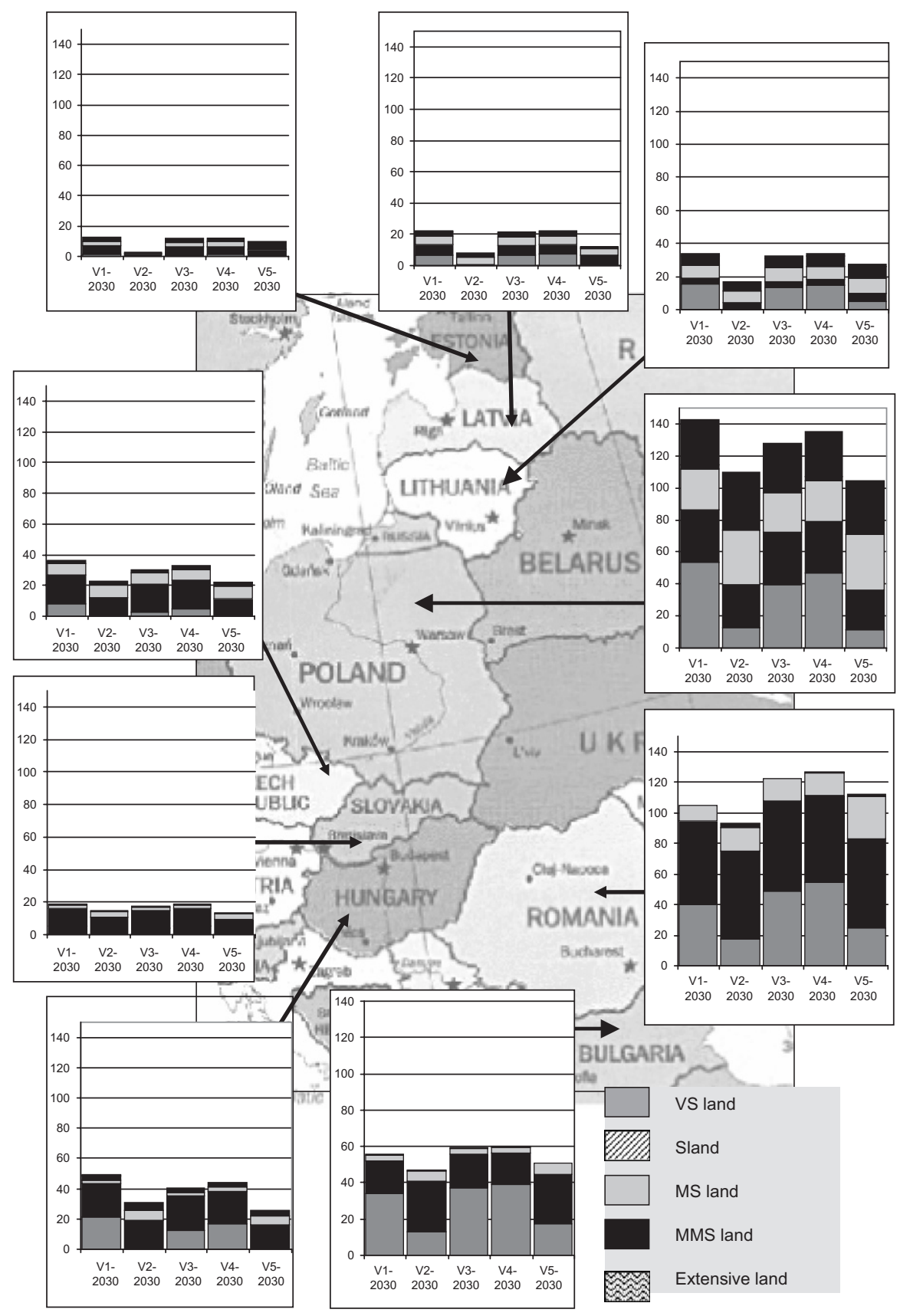

Fig. 5. Amount of available land (in 100,000 ha) in CEEC on country level for energy crop production under selected scenarios. 
selected agricultural production system, as can be shown by the following examples:

- In the example of the V5 scenario the surplus land availability for energy crop production is low. Here, larger areas than in other scenarios are needed for the production of fodder crops with low protein content because the meat production comes from an extensive livestock production system.

- The allocation procedure of the required food demand over the total available land is differentiated per scenario. This means for example that allocation in the V1 ("open trade") scenario takes place over the complete CEEC region, while allocation in the V4 (regionally oriented) scenario takes place within a Nuts2 region level. The allocation over the whole area of CEEC sets more land free for energy crop production because there are more possibilities to allocate the crops to areas where they find good eco-physiological conditions for performing high yields.

- The V1 scenario is defined by an advanced production system characterized by high yield levels. The V2 scenario, on the other hand, is defined by the current agricultural production systems, that generally results in low yield levels. This means that in the V1 scenario, with high yields, less land area is needed for the same food production than under the $\mathrm{V} 2$ scenario.

\subsection{Biomass production potential in the CEEC}

The total biomass production potential, including agricultural residues, biomass derived from energy crops, forest residues and surplus forestland, for all CEEC countries is shown in Table 4. Note that biomass potentials of energy crops are shown for the whole crop and based on the data sources as indicated in Table 1.

The model shows in general good potentials for the lignocellulosic crops (willow, poplar and miscanthus) in the CEEC. Among these crops, willow gives the best results.
Rapeseed and sugar beet show good potentials as well. The different performance of energy crops is due to differences in land suitability and in genetic yield potentials of the crops. For crops like willow, sugar beet and rapeseed large areas of suitable land are available in the CEEC. The climatic conditions for the energy crops sweet sorghum and sunflower, that are adapted to warmer climates, are not suitable in the Baltic States, Poland, Czech Republic and Slovakia. They can mainly be grown in Romania and their overall potential in all CEEC is therefore low.

Energy crops have different genetic yield potentials. Table 5 shows the yield levels for the selected energy crops on a country level for the various agricultural production systems. In Table 5, yield levels are shown for the whole crop of Sugar beet. Sugar beet is a comparatively powerful crop with total average biomass yields of about $18 \mathrm{t} \mathrm{DM}$ (of which $35 \%$ are leaves) compared to willow with about $10 \mathrm{t}$ DM (values for Germany, sources [59,60]). Conventional crops, however, contain components that are generally not collected for biomass production, due to their low efficiency, as they are difficult to collect or have no good properties for energetic use. This is for example true for the leaves of sugar beet and potato. Therefore, Table 6 shows the biomass potential results for sugar beet and potato based on the beet only.

Fig. 6 shows per country the total biomass potential results from the energy crop willow; Potentials vary strongly between different scenarios. These differences reflect the influences of the indicators that were used to describe the assumptions and story lines of the scenarios. A scenario assumption is, for example, that sugar beet production for food decreases in the V1 scenario due to free trade of sugar and a strong decline in financial support for this crop in Europe. The result of this scenario assumption is that more suitable land is available for sugar beet production for bio-energy in the V1 scenario than in the other scenarios.

Other influences of the scenario assumptions become visible by the example of the total biomass potential (based

Table 4

Biomass potential (in EJ) from energy crops, agricultural residues, forest residues and surplus forest for the sum of all Central and Eastern European countries

\begin{tabular}{|c|c|c|c|c|c|}
\hline \multirow{2}{*}{$\begin{array}{l}\text { Selected energy crop in } \\
\text { scenario }\end{array}$} & \multicolumn{5}{|c|}{ Scenarios VIEWLS } \\
\hline & V1 2030 & V2 2030 & V3 2030 & V4 2030 & V5 2030 \\
\hline \multicolumn{6}{|l|}{ Lignocellulosic crops } \\
\hline Willow & 11.65 & 4.86 & 8.65 & 10.67 & 5.47 \\
\hline Poplar & 10.27 & 4.35 & 7.63 & 9.25 & 4.85 \\
\hline Miscanthus & 10.93 & 5.71 & 9.08 & 10.03 & 6.28 \\
\hline \multicolumn{6}{|l|}{ Conventional crops } \\
\hline Rapeseed (whole crop) & 9.94 & 5.28 & 9.18 & 9.00 & 5.67 \\
\hline Sunflower (whole crop) & 5.95 & 3.46 & 5.24 & 4.97 & 3.49 \\
\hline Sugar beet (beet) & 8.32 & 3.55 & 6.42 & 7.27 & 3.59 \\
\hline Potato (tuber) & 6.06 & 2.03 & 4.65 & 4.94 & 2.06 \\
\hline Sweet Sorghum (whole crop) & 7.20 & 2.56 & 5.81 & 6.64 & 2.94 \\
\hline
\end{tabular}


Table 5

Yield potential for selected energy crops shown for various agricultural production systems, CEEC and land suitability classes

\begin{tabular}{|c|c|c|c|c|c|c|c|c|c|c|c|c|}
\hline & \multicolumn{4}{|c|}{ Willow } & \multicolumn{4}{|c|}{ Miscanthus } & \multicolumn{4}{|c|}{ Sugar beet (whole crop) ${ }^{\mathrm{a}}$} \\
\hline & VS & $\mathrm{S}$ & MS & $\mathrm{mMS}$ & VS & $\mathrm{S}$ & MS & $\mathrm{mMS}$ & VS & $\mathrm{S}$ & MS & $\mathrm{mMS}$ \\
\hline \multicolumn{13}{|c|}{ Current agricultural production system } \\
\hline EE & 9.05 & 6.71 & 4.83 & 1.86 & 0.10 & 0.10 & 0.10 & 0.10 & 10.90 & 9.01 & 7.44 & 3.66 \\
\hline LT & 10.13 & 7.50 & 4.96 & 2.40 & 4.18 & 3.09 & 2.29 & 1.70 & 12.47 & 10.29 & 7.05 & 3.37 \\
\hline LV & 9.71 & 7.20 & 4.80 & 2.33 & 1.67 & 1.24 & 0.92 & 0.68 & 12.53 & 10.04 & 7.82 & 3.45 \\
\hline PL & 10.60 & 7.85 & 5.29 & 1.77 & 12.09 & 8.96 & 6.64 & 1.83 & 20.18 & 16.71 & 11.56 & 5.41 \\
\hline $\mathrm{RO}$ & 10.15 & 7.67 & 5.22 & 2.01 & 14.11 & 10.87 & 7.79 & 4.10 & 13.68 & 10.61 & 7.38 & 4.17 \\
\hline $\mathrm{BG}$ & 11.01 & 8.02 & 5.27 & 1.44 & 13.67 & 10.55 & 7.50 & 4.14 & 14.19 & 10.17 & 7.91 & 4.56 \\
\hline $\mathrm{HU}$ & 10.36 & 7.97 & 5.33 & 1.88 & 14.44 & 11.25 & 8.01 & 3.81 & 18.92 & 16.01 & 12.86 & 7.57 \\
\hline $\mathrm{CZ}$ & 9.05 & 7.65 & 5.11 & 1.99 & 12.20 & 9.04 & 6.84 & 2.92 & 19.94 & 15.61 & 11.36 & 5.41 \\
\hline SK & 9.62 & 7.83 & 5.32 & 1.98 & 12.26 & 9.82 & 6.98 & 2.84 & 16.72 & 16.60 & 11.16 & 5.02 \\
\hline \multicolumn{13}{|c|}{ High input production system } \\
\hline $\mathrm{EE}$ & 12.93 & 9.58 & 6.91 & 2.66 & 0.10 & 0.10 & 0.10 & 0.08 & 0.10 & 19.07 & 14.98 & 3.14 \\
\hline LT & 14.47 & 10.72 & 7.08 & 3.43 & 0.10 & 0.10 & 0.10 & 2.43 & 26.88 & 22.10 & 16.25 & 3.35 \\
\hline LV & 13.88 & 10.28 & 6.86 & 3.32 & 0.10 & 0.10 & 0.10 & 0.97 & 25.76 & 18.79 & 15.80 & 5.71 \\
\hline PL & 15.14 & 11.21 & 7.55 & 2.52 & 17.28 & 12.80 & 9.48 & 2.61 & 30.16 & 24.58 & 17.30 & 8.19 \\
\hline $\mathrm{RO}$ & 14.51 & 10.95 & 7.46 & 2.87 & 20.16 & 15.53 & 11.13 & 5.85 & 24.25 & 23.93 & 17.16 & 8.97 \\
\hline $\mathrm{BG}$ & 15.72 & 11.45 & 7.53 & 2.05 & 19.54 & 15.08 & 10.71 & 5.91 & 20.72 & 20.80 & 15.08 & 5.58 \\
\hline $\mathrm{HU}$ & 14.81 & 11.39 & 7.61 & 2.69 & 20.63 & 16.07 & 11.45 & 5.45 & 25.02 & 22.96 & 16.57 & 8.81 \\
\hline $\mathrm{CZ}$ & 12.93 & 10.93 & 7.30 & 2.85 & 17.43 & 12.91 & 9.77 & 4.17 & 29.51 & 23.77 & 17.08 & 8.26 \\
\hline SK & 13.74 & 11.19 & 7.60 & 2.82 & 17.52 & 14.03 & 9.97 & 4.06 & 24.60 & 24.08 & 17.22 & 8.57 \\
\hline \multicolumn{13}{|c|}{ Ecological production system } \\
\hline $\mathrm{EE}$ & 10.35 & 7.66 & 5.53 & 2.12 & 0.10 & 0.10 & 0.10 & 0.10 & 15.81 & 13.07 & 10.80 & 5.24 \\
\hline LT & 11.58 & 8.58 & 5.67 & 2.74 & 0.10 & 0.10 & 0.10 & 0.10 & 18.69 & 15.44 & 11.29 & 5.49 \\
\hline LV & 11.10 & 8.22 & 5.49 & 2.66 & 0.10 & 0.10 & 0.10 & 0.10 & 18.44 & 15.24 & 11.15 & 4.87 \\
\hline PL & 12.11 & 8.97 & 6.04 & 2.02 & 13.82 & 10.24 & 7.58 & 2.09 & 20.66 & 16.71 & 11.56 & 5.41 \\
\hline $\mathrm{RO}$ & 11.60 & 8.76 & 5.97 & 2.29 & 16.13 & 12.43 & 8.91 & 4.68 & 20.32 & 15.77 & 11.64 & 5.62 \\
\hline $\mathrm{BG}$ & 12.58 & 9.16 & 6.03 & 1.64 & 15.63 & 12.06 & 8.57 & 4.73 & 22.36 & 18.48 & 15.91 & 9.09 \\
\hline $\mathrm{HU}$ & 11.84 & 9.11 & 6.09 & 2.15 & 16.50 & 12.86 & 9.16 & 4.36 & 21.19 & 16.01 & 12.86 & 7.57 \\
\hline $\mathrm{CZ}$ & 10.35 & 8.74 & 5.84 & 2.28 & 13.94 & 10.33 & 7.82 & 3.34 & 20.88 & 15.61 & 11.36 & 5.41 \\
\hline SK & 10.99 & 8.95 & 6.08 & 2.26 & 14.02 & 11.22 & 7.98 & 3.25 & 20.65 & 16.60 & 11.16 & 5.02 \\
\hline \multicolumn{13}{|c|}{ High input and advanced technology production system } \\
\hline $\mathrm{EE}$ & 16.81 & 12.46 & 8.98 & 3.45 & 0.10 & 0.10 & 0.10 & 0.10 & 0.10 & 24.80 & 19.47 & 10.59 \\
\hline LT & 18.81 & 13.93 & 9.21 & 4.46 & 6.72 & 4.97 & 3.68 & 2.73 & 34.94 & 28.73 & 21.12 & 10.86 \\
\hline LV & 18.04 & 13.36 & 8.92 & 4.32 & 2.69 & 1.99 & 1.47 & 1.09 & 33.48 & 24.42 & 20.54 & 8.73 \\
\hline PL & 19.68 & 14.58 & 9.82 & 3.28 & 19.43 & 14.40 & 10.66 & 2.94 & 39.20 & 31.95 & 22.48 & 10.65 \\
\hline $\mathrm{RO}$ & 18.86 & 14.24 & 9.69 & 3.73 & 22.68 & 17.48 & 12.53 & 6.58 & 31.52 & 31.11 & 22.31 & 11.66 \\
\hline $\mathrm{BG}$ & 20.44 & 14.89 & 9.79 & 2.67 & 21.98 & 16.96 & 12.05 & 6.65 & 26.94 & 27.04 & 19.60 & 8.56 \\
\hline $\mathrm{HU}$ & 19.25 & 14.80 & 9.90 & 3.50 & 23.21 & 18.08 & 12.88 & 6.13 & 32.52 & 29.85 & 21.55 & 11.46 \\
\hline $\mathrm{CZ}$ & 16.81 & 14.21 & 9.49 & 3.70 & 19.61 & 14.52 & 10.99 & 4.69 & 38.37 & 30.90 & 22.20 & 10.73 \\
\hline SK & 17.68 & 14.55 & 9.88 & 3.67 & 19.71 & 15.78 & 11.22 & 4.57 & 31.98 & 31.30 & 22.39 & 11.15 \\
\hline
\end{tabular}

$\mathrm{VS}=$ very suitable, $\mathrm{S}=$ suitable, $\mathrm{MS}=$ moderately suitable, $\mathrm{mMs}=$ marginally suitable in $\mathrm{tDM} / \mathrm{ha} / \mathrm{yr}$.

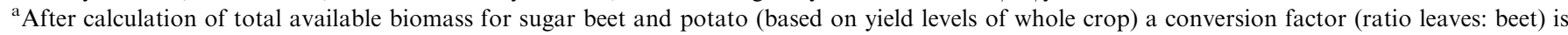
used to come to the available biomass for the beet only.

on energy crop rapeseed) for the Nuts-2 regions in Poland for the scenarios V1 2030 and V5 2030 (see Fig. 7a,b). There are not only differences in the total biomass potential between the two scenarios, but also in the sources of the biomass potentials. In the ecological (V5) scenario a large percentage of the agricultural residues remain in the fields for reasons of soil conservation and management of nutrients. That limits the economic availability of residues in this scenario (see low amount of agricultural residues in Fig. 7b). Biomass potentials derived from forestry residues and surplus forestland are relatively high in the V4 scenario due to a decrease in international trade of wood which leads to an increased productivity in the forest sector in the CEEC. The availability of biomass from forest residues and surplus forestland are, on the other hand, relatively low in the V5 scenario due to ecological limitations.

Biomass from energy crops is the sum of the available land for energy crop production multiplied by the yield factor of the energy crop itself. The scenarios produce different results in the total surplus of available land for energy crop production in the CEEC. Beside this, yield levels for energy crops vary between scenarios as the 
Table 6

Land rents in $€ / \mathrm{ha} / \mathrm{yr}$ for different scenarios used in biomass potential assessment and for the different land suitabilities

\begin{tabular}{lllll}
\hline Land suitability & VS & $\mathrm{S}$ & $\mathrm{MS}$ & $\mathrm{mMs}$ \\
\hline V2 scenario: current & cost level in $C E E C$ & & \\
Estonia & $€ 27,-$ & $€ 23,-$ & $€ 19,-$ & $€ 15,-$ \\
Lithuania & $€ 42,-$ & $€ 32,-$ & $€ 22,-$ & $€ 12,-$ \\
Latvia & $€ 44,-$ & $€ 35,-$ & $€ 26,-$ & $€ 17,-$ \\
Poland & $€ 113,-$ & $€ 35,-$ & $€ 29,-$ & $€ 10,-$ \\
Romania & $€ 74,-$ & $€ 60,-$ & $€ 46,-$ & $€ 32,-$ \\
Bulgaria & $€ 58,-$ & $€ 41,-$ & $€ 28,-$ & $€ 20,-$ \\
Hungary & $€ 48,-$ & $€ 45,-$ & $€ 32,-$ & $€ 18,-$ \\
Czech Republic & $€ 38,-$ & $€ 32,40$ & $€ 16,-$ & $€ 10,-$ \\
Slovakia & $€ 13,-$ & $€ 11,-$ & $€ 8,-$ & $€ 3,-$ \\
Other scenarios in model & & & \\
V1 & $€ 88,-$ & $€ 74,-$ & $€ 59,-$ & $€ 44,-$ \\
V3 & $€ 110,-$ & $€ 92,-$ & $€ 74,-$ & $€ 55,-$ \\
V4 & $€ 132,-$ & $€ 110,-$ & $€ 90,-$ & $€ 66,-$ \\
V5 & $€ 178,-$ & $€ 149,-$ & $€ 127,-$ & $€ 104,-$ \\
\end{tabular}

$\mathrm{VS}=$ very $\quad$ suitable, $\quad \mathrm{S}=$ suitable, $\quad \mathrm{MS}=$ moderately $\quad$ suitable, $\mathrm{mMs}=$ marginally suitable.

scenarios contain - as one of the indicators - different agricultural production systems. These two factors result in different outcomes for the biomass potential assessment per scenario.

\subsection{Production costs in the CEEC for the selected scenarios}

The biomass potential for conventional crops is calculated for the whole crop. This means that the total costs (in $€ /$ ha) are divided through the biomass yield of the whole crop to come to the final cost estimation in $€ / G J$. As also mentioned in Section 2.4, the methodology for the cost calculation of biomass production is a bottom-up approach that requires a data input for a wide range of cost items.

Table 6 shows information about the land rents in $€ /$ ha/yr used for the different countries and scenarios on a country level. Table 7 shows the information used for wages in $€ / h$. The assumed wages in $€ / h$ for the different scenarios are based on the current wages for farmers in different countries in the EU. In scenario V2 the current wages in CEEC are used. Table 8 gives an example for the range of data included for the cost calculation for biomass production, here for rapeseed production in Poland for the V2 scenario.

Figs. 8-11 shows the cost supply curves for the four selected energy crops willow, miscanthus, sugar beet and rapeseed for the CEEC as a whole. The cost levels in $€ / G J$ (for the whole crop!) vary per scenario. In general, the curve starts with the supply of agricultural and forest residues as these sources have the lowest production costs in $€ / G J$. Subsequently, the curve continues with the supply from energy crop production, starting with the biomass that can be produced cheapest (generally on VS land) and ending with the most expensively produced biomass. Fig. 8 shows for example that the bulk of the costs are generally closer situated at the minimum cost level than at the maximum cost level.

Biomass production costs vary not only between scenarios, but also between regions within a country. This is shown in Table 9 for the energy crop willow.

Two factors, the regional level of crop yields and the regional cost levels, cause these regional differences. To give an example on cost differences, wages in Romania are at this moment only $29 \%$ of the wages in Poland. This difference in cost items also appears in costs per inputs or costs for land. As the cost-supply curves show, among the crops, biomass from willow and other lignocellulosic crops is relatively competitive. Because of its high whole crop yields sugar beet also shows comparatively low biomass production costs in $€ /$ GJ HHV (see Fig. 11). Sweet sorghum turns out very expensive in those countries where the climatic conditions and low land suitability do not allow for high yields.

The scenarios in the model contain a set of indicators that influence the total production costs in $€ / \mathrm{ha} / \mathrm{yr}$ and in $€ /$ GJ HHV for a selected energy crop, as can be shown by the example of production costs for willow biomass in Poland. Fig. 12(a) shows that the V5 scenario has the highest production costs in $€ / \mathrm{ha} / \mathrm{yr}$, followed by subsequently the V4, V3, V2 and V1 scenario.

The high cost levels for V5 scenario can be explained by, among other things, the high costs for land in this scenario (see Table 2) and the higher machinery and fixed costs that arise from the smaller scale production of energy crops in this ecological scenario.

Fig. 12(b) shows costs for willow production in Poland in $€ / G J ~ H H V$. The biomass production costs in $€ /$ GJ HHV are still highest for the V5 scenario. However, although the V4 scenario has higher production costs in $€ / \mathrm{ha} / \mathrm{yr}$ than the $\mathrm{V} 2$ and V3 scenario, this scenario manages to achieve lower production costs in $€ / \mathrm{GJ}$ HHV than $\mathrm{V} 2$ and V3. This difference can be explained by the impact of the agricultural production systems in the different scenarios (see Table 2). Under the 'high input and advanced technology production system' in the V4 scenario high yields are attained. This means that, although production costs are high in $€ /$ ha, costs in $€ / t \mathrm{DM}$ are lower compared to the V2 and V3 scenarios because more biomass per ha is harvested. High production costs in both $€ / \mathrm{ha} / \mathrm{yr}$ as well as in $€ / t \mathrm{DM}$ in the V5 scenario are due to the lower yields under the ecological production system.

\section{Discussion and conclusions}

The methodology applied here only allows modelling the production of one biomass crop on all areas available for biomass production in the CEEC. An optimization of biomass production will require that for every region the most suitable crop (in yield level and cost performance) needs to be selected. The model does not include restrictions to the share of one crop with other crops in 


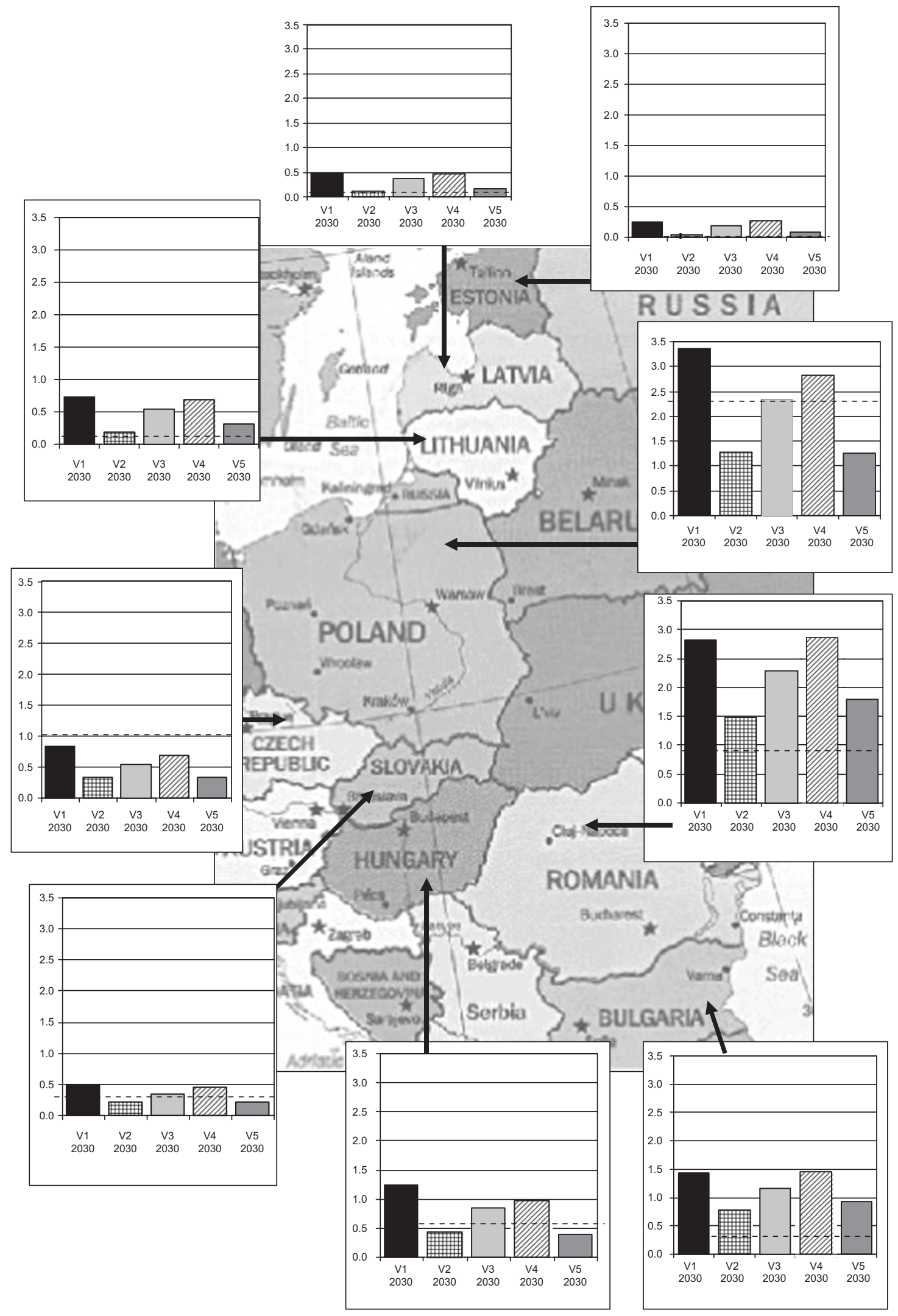

Fig. 6. Biomass potential in CEEC for selected scenarios on country level (in EJ). The total potential is the sum of residues, surplus forest and energy crop production. The selected energy crop is willow derived from VS, S, MS and mMS land on country level. The line in the graph shows the current final energy consumption on country level in EJ for the year 2000, received from DG TREN [63]. 
(a) 350.0

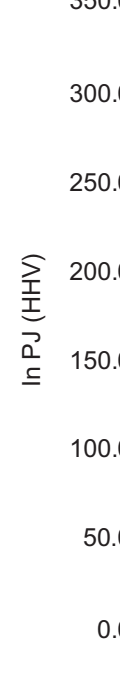

0.0

Pl01 Pl02 Pl03 Pl04 PL05 PL06 PL07 PL08 PL09 PL0A PL0B PL0C PL0D PL0E PL0F PL0G

Nuts-2 regions

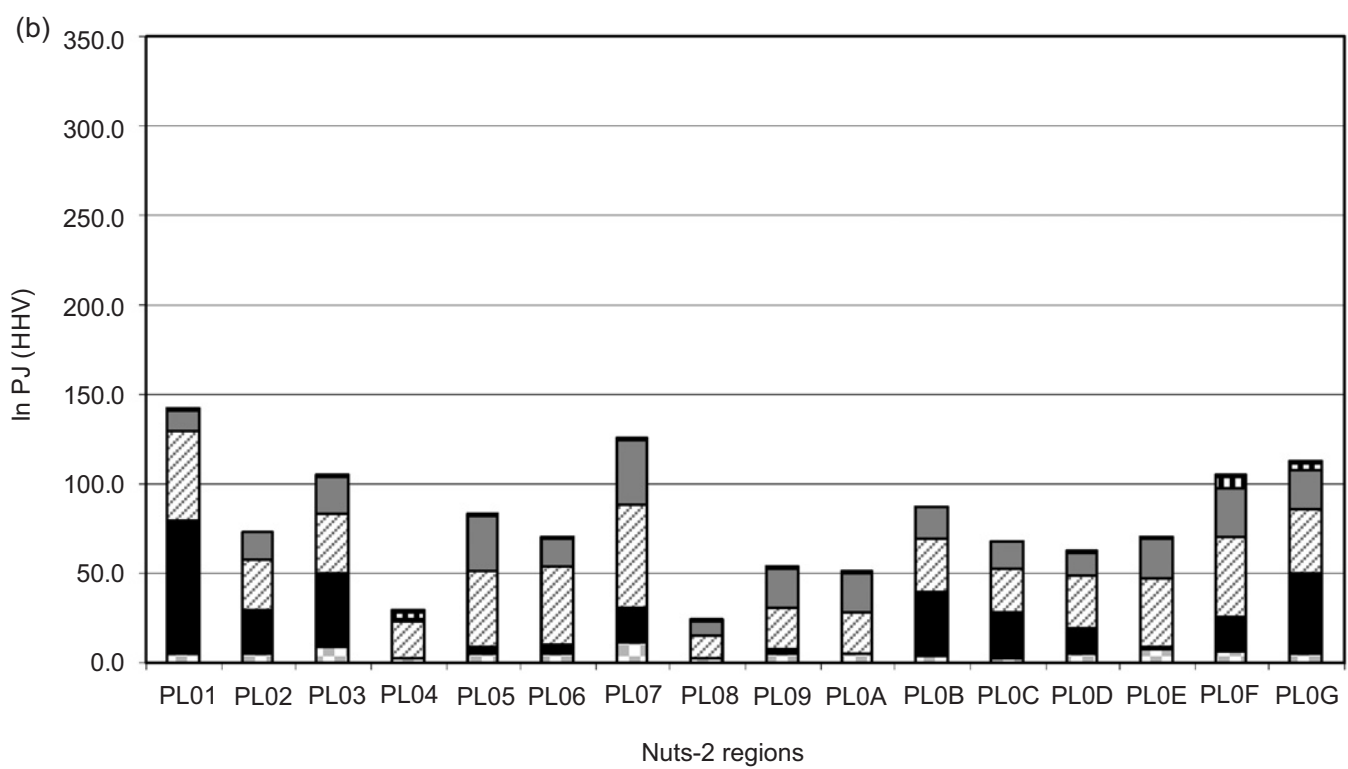

Extra marginal land

$\square$ Wood surplus forest

Forest residues

- Energy crops mMS land

口Energy crops MS land

$\square$ Energy crops $S$ land

- Energy crops VS land

$\square$ Agricultural residues

\begin{tabular}{l} 
Extra marginal land \\
W Wood surplus forest \\
G Forest residues \\
Energy crops mMS land \\
Energy crops MS land \\
Energy crops S land \\
$\square$ Energy crops VS land \\
\hline
\end{tabular}
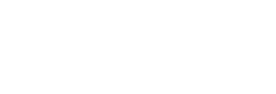

Fig. 7. (a) Total biomass potential in PJ for Nuts-2 regions in Poland for selected energy crop rapeseed, scenario V1 2030. (b). Biomass potential in PJ for Nuts-2 regions in Poland for selected energy crop rapeseed, scenario V5 2030.

Table 7

Wages in $€$ per hour for different scenarios used in the biomass potential assessment

\begin{tabular}{|c|c|c|c|c|c|c|c|c|c|}
\hline \multirow[t]{2}{*}{ Scenarios } & \multicolumn{9}{|c|}{ Countries included in biomass potential assessment } \\
\hline & EE & $\mathrm{LT}$ & LV & PL & RO & BG & $\mathrm{HU}$ & $\mathrm{CZ}$ & SK \\
\hline V1 & $€ 14,63$ & $€ 14,63$ & $€ 14,63$ & $€ 14,63$ & $€ 14,63$ & $€ 14,63$ & $€ 14,63$ & $€ 14,63$ & $€ 14,63$ \\
\hline $\mathrm{V} 2$ & $€ 1,31$ & $€ 1,41$ & $€ 1,18$ & $€ 2,52$ & $€ 0,67$ & $€ 0,59$ & $€ 1,46$ & $€ 1,78$ & $€ 1,28$ \\
\hline V3 & $€ 12,22$ & $€ 12,22$ & $€ 12,22$ & $€ 12,22$ & $€ 12,22$ & $€ 12,22$ & $€ 12,22$ & $€ 12,22$ & $€ 12,22$ \\
\hline V4 & $€ 14,63$ & $€ 14,63$ & $€ 14,63$ & $€ 14,63$ & $€ 14,63$ & $€ 14,63$ & $€ 14,63$ & $€ 14,63$ & $€ 14,63$ \\
\hline V5 & $€ 12,22$ & $€ 12,22$ & $€ 12,22$ & $€ 12,22$ & $€ 12,22$ & $€ 12,22$ & $€ 12,22$ & $€ 12,22$ & $€ 12,22$ \\
\hline
\end{tabular}

rotation schemes. For sugar beet and rapeseed, both are already produced in large scale, such restrictions (due to phytosanitary constraints they can only appear every third year in the rotation and are therefore limited to a third of the agricultural area) can limit the biomass potential of these crops. These constraints have to be taken into consideration in further development of the model. 
Table 8

Cost items included per crop for calculation, here as example for the crop rapeseed in $€ /$ ha yr for country Poland for V2 scenario 2030

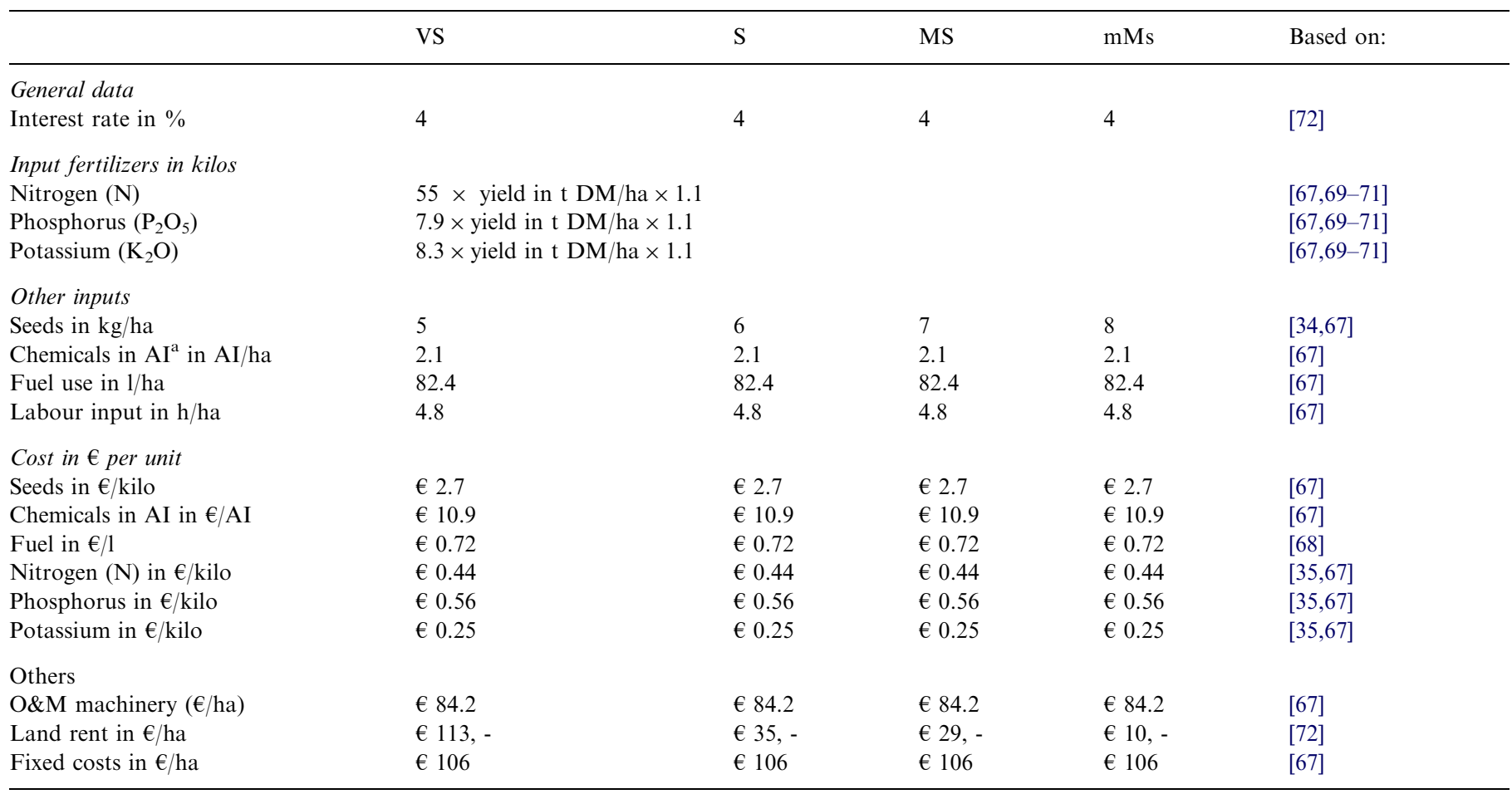

${ }^{\mathrm{a}} \mathrm{AI}$ : active ingredients in chemicals.

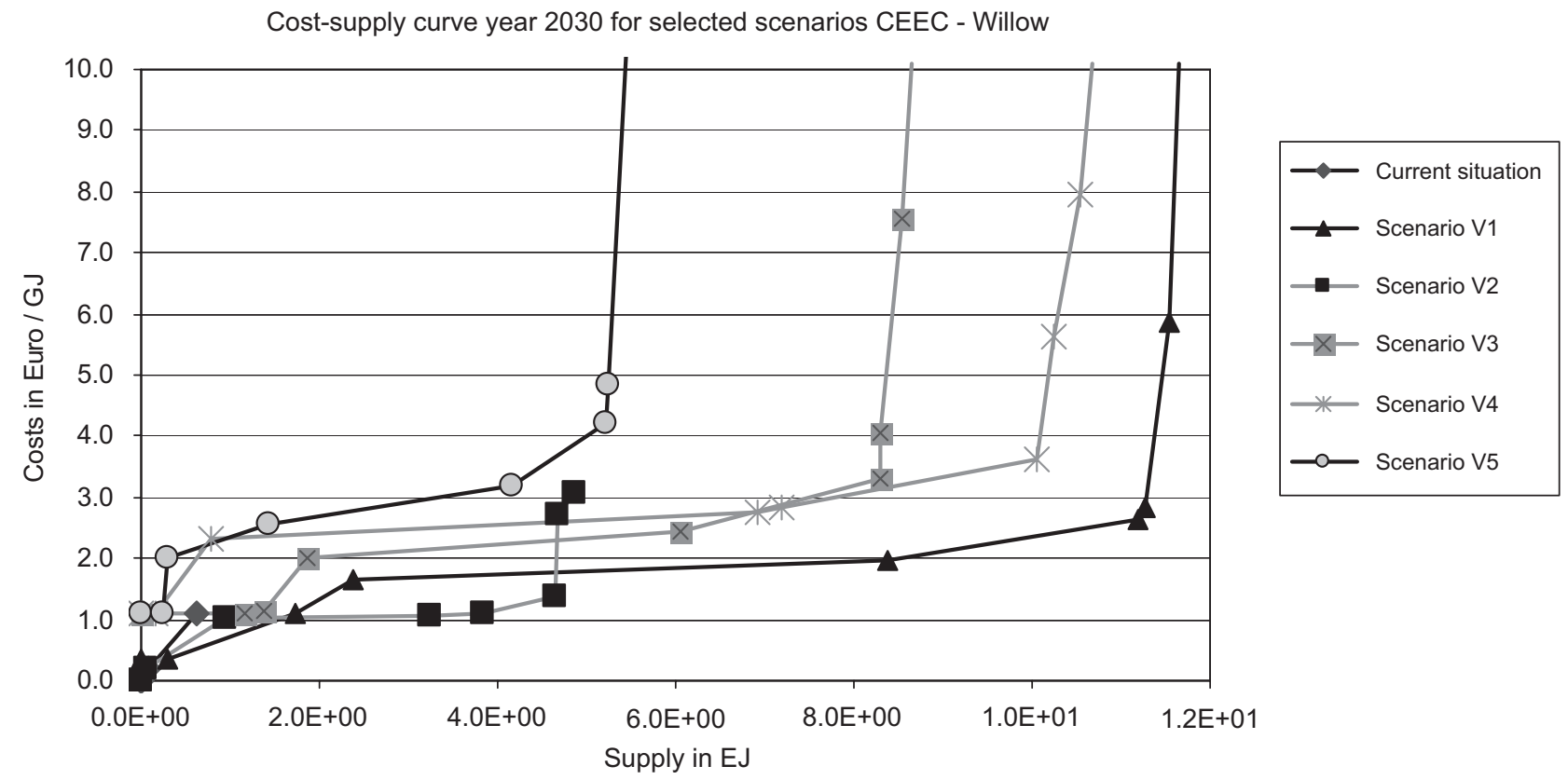

Fig. 8. Cost-supply curve for all CEEC countries, based on willow as selected energy crop. Cost levels are average production costs, based on the \% of available potential per individual CEEC country.

An uncertainty in the assessment of land availability for the production of energy crops is the demand for land for food and feed production. FAO predictions for the expected food and feed demand in the CEEC were used to estimate the amount of land needed in future for food and feed production in the CEEC. This estimate does, however, only reflect a situation in which the food and feed demand within the studies region is included and not with regard to (optimizing) global food and feed demand. Therefore, land demand for food and feed production stays 


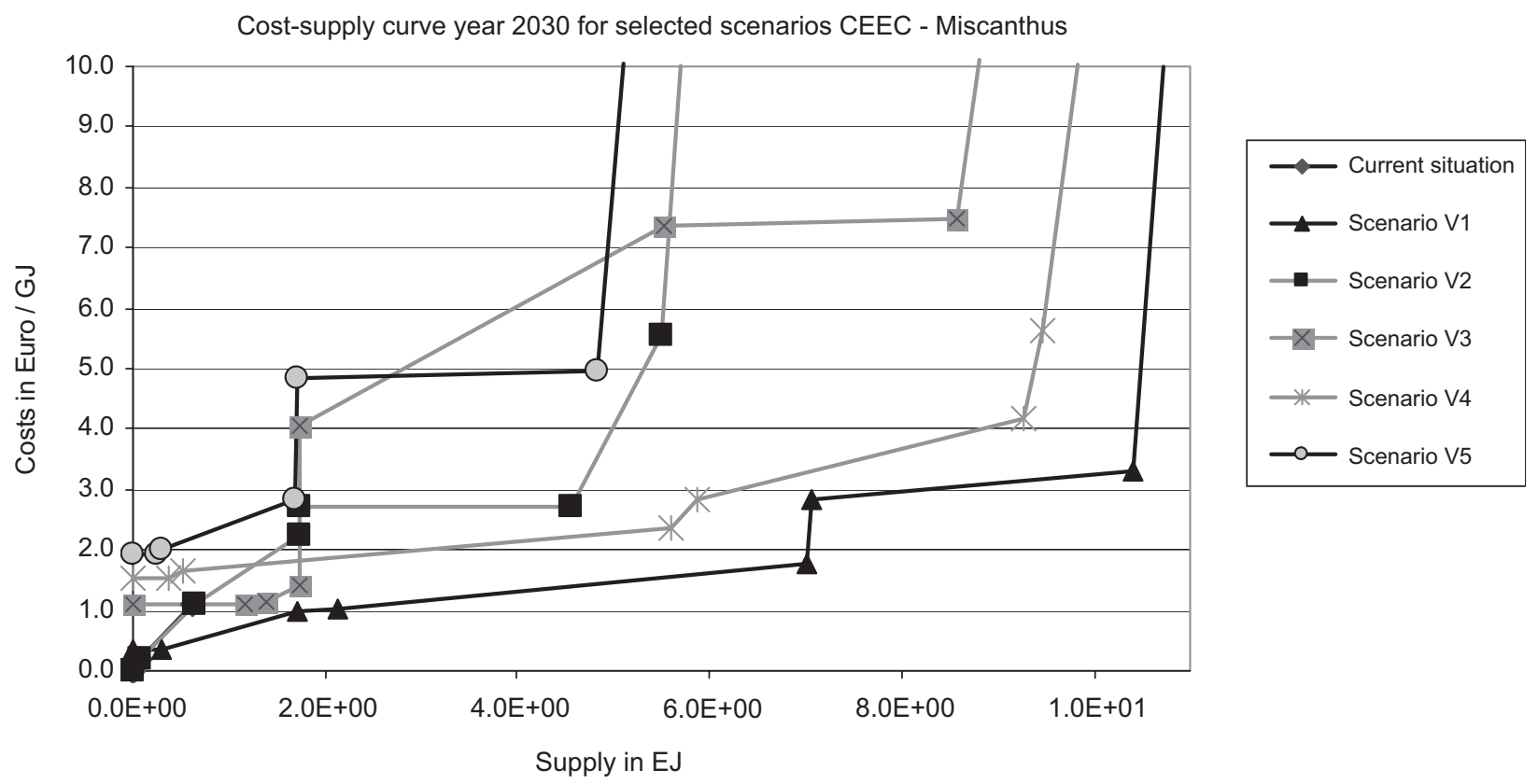

Fig. 9. Cost-supply curve for all CEEC countries, based on miscanthus as selected energy crop. Cost levels are average production costs, based on the \% of available potential per individual CEEC country.

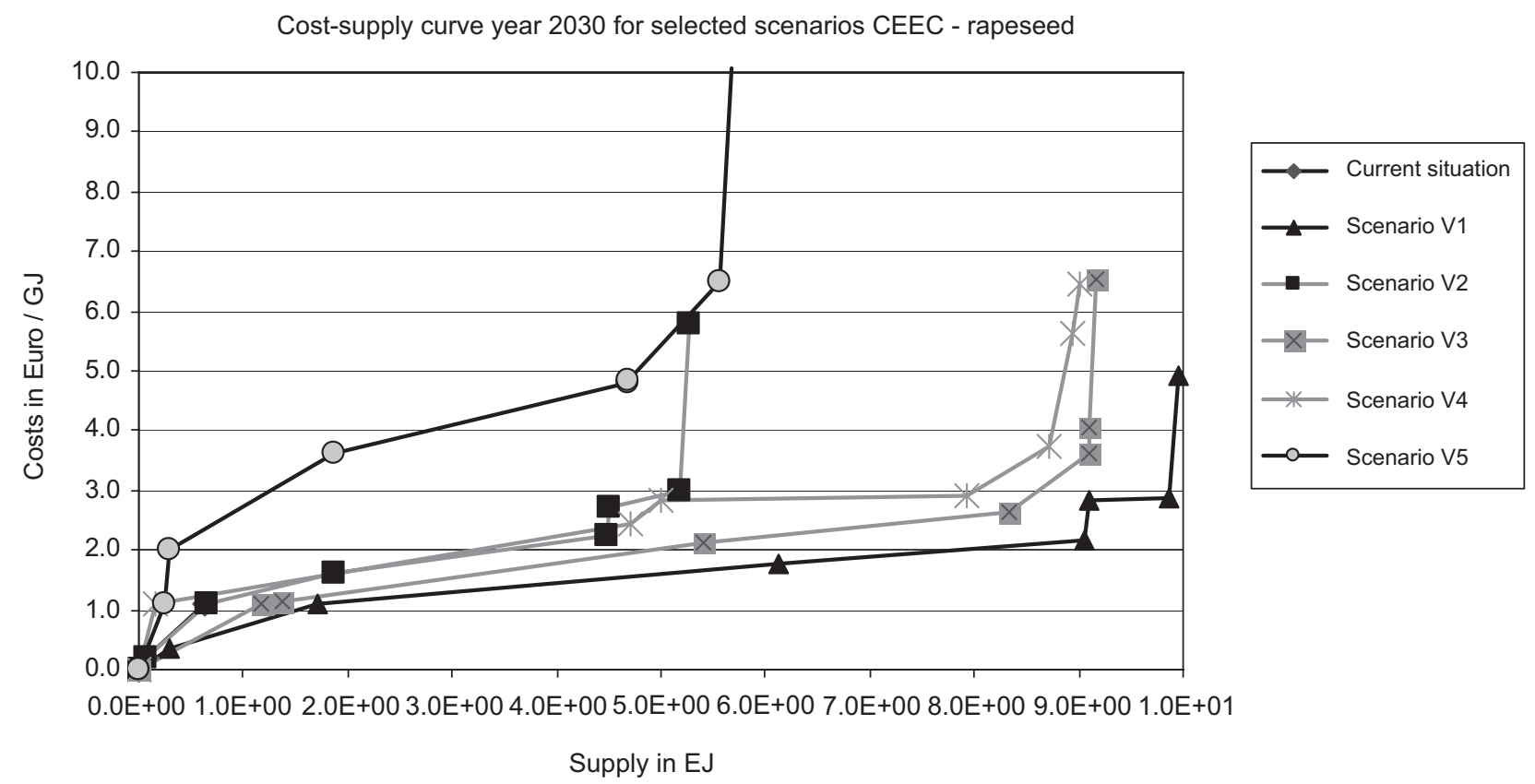

Fig. 10. Cost-supply curve for all CEEC countries, based on rapeseed as selected energy crop. Cost levels are average production costs, based on the \% of available potential per individual CEEC country.

an uncertainty in the prediction of land availability for energy crop production.

In the approach taken here (based on the IIASA approach, see also [61]) it is assumed that all land area minus forestry and urban land would be available for agricultural production The presence of nature reserve areas, which do not include forest, or grassland areas or abandoned mining or industrial areas, are also subtracted from the area of available land. This means that the model contains a large area of agricultural land available in CEEC. However, in reality, the actual use and availability of agricultural land areas in the CEEC is expected to be lower. This can be partly explained by the large areas of current abandoned and unused land areas in the CEEC. Specific data on these kinds of land areas are missing or hidden in the statistics. As part of these abandoned lands might be planned reserved for nature conservation areas, there might be an overestimation in the biomass potential 
Cost-supply curve year 2030 for selected scenarios CEEC - sugar beet

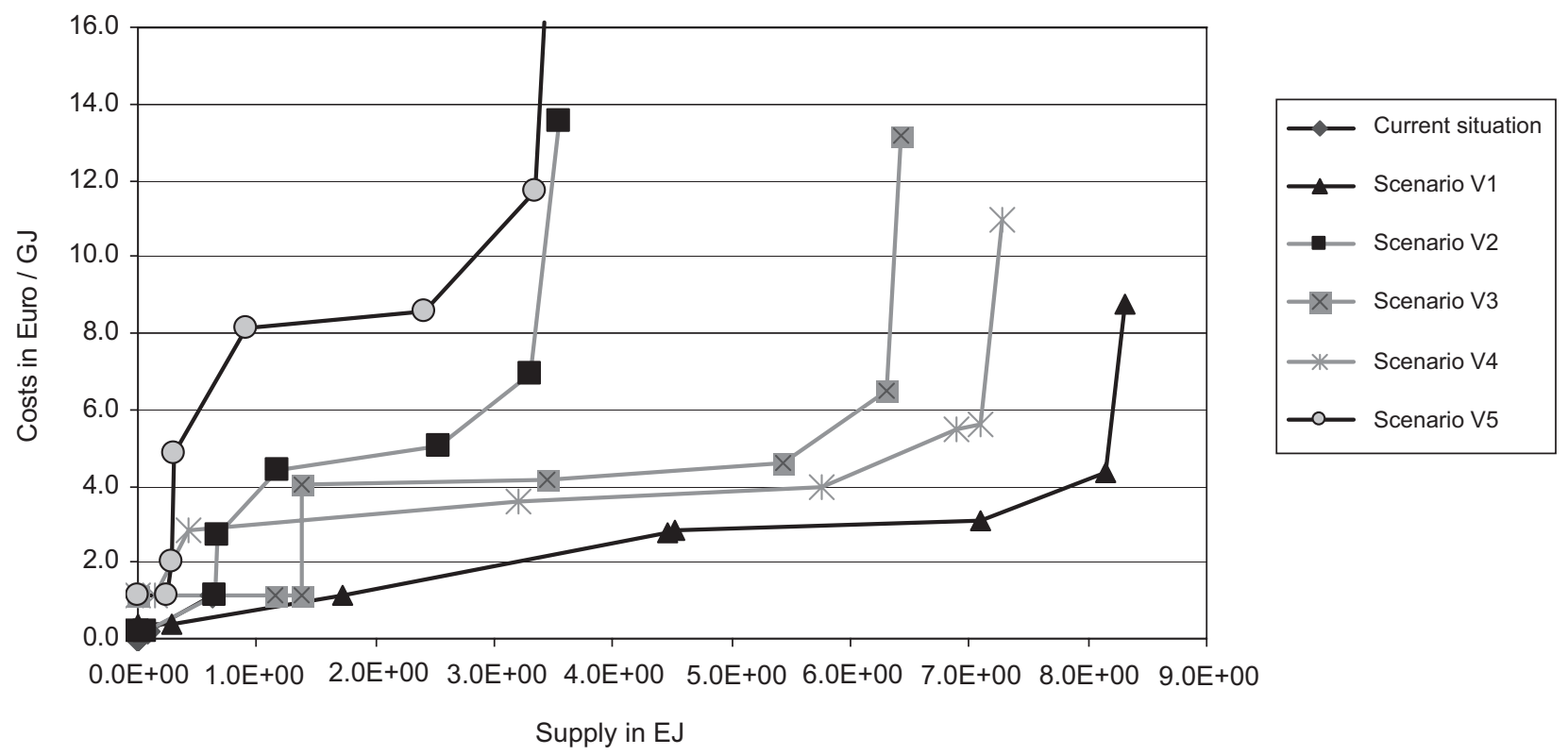

Fig. 11. Cost-supply curve for all CEEC countries, based on sugar beet as selected energy crop. Cost levels are average production costs, based on the \% of available potential per individual CEEC country.

Table 9

Range of biomass production costs in CEEC countries in $€$ per GJ for selected energy crops, shown for a set of scenarios

\begin{tabular}{|c|c|c|c|c|c|c|c|c|c|c|}
\hline \multirow[t]{2}{*}{ Selected energy crops } & \multicolumn{2}{|c|}{ V1-2030 } & \multicolumn{2}{|c|}{ V2-2030 } & \multicolumn{2}{|c|}{ V3-2030 } & \multicolumn{2}{|c|}{ V4-2030 } & \multicolumn{2}{|c|}{ V5-2030 } \\
\hline & Min & $\operatorname{Max}$ & Min & Max & Min & Max. & Min & Max & Min & $\operatorname{Max}$ \\
\hline $\mathrm{EE}$ & 1.8 & 6.2 & 1.1 & 4.0 & 2.2 & 8.0 & 2.5 & 8.2 & 2.9 & 11.3 \\
\hline LT & 1.7 & 4.9 & 1.1 & 3.1 & 2.0 & 6.3 & 2.3 & 6.7 & 2.6 & 8.8 \\
\hline LV & 1.7 & 5.1 & 1.1 & 3.3 & 2.1 & 6.5 & 2.4 & 6.9 & 2.7 & 9.1 \\
\hline BG & 1.6 & 8.0 & 0.9 & 4.5 & 1.9 & 10.3 & 2.2 & 10.8 & 2.5 & 14.5 \\
\hline $\mathrm{HU}$ & 1.7 & 6.2 & 1.0 & 4.1 & 2.0 & 8.0 & 2.3 & 8.4 & 1.8 & 4.4 \\
\hline $\mathrm{CZ}$ & 1.8 & 5.8 & 0.4 & 1.1 & 2.2 & 7.5 & 2.6 & 7.9 & 2.9 & 10.6 \\
\hline SK & 1.7 & 5.9 & 1.0 & 3.7 & 2.1 & 7.6 & 2.4 & 8.0 & 1.8 & 4.2 \\
\hline
\end{tabular}

results for some regions. In future analysis a larger amount of land area for planning nature conservation might be required.

The countries with the biggest land areas, Poland and Romania, clearly have the highest biomass potentials. Also on Nuts-3 regional level there is a clear correlation between the amount of arable land and the potential for biomass production. Apart from large land areas also favourable eco-physiological production conditions, like fertile soils, can characterize a region with high biomass potential. This is not only true in terms of potentials, but also for costs. The results of the cost analysis done here show that the biomass production costs (per tonne or GJ) decrease with increasing land quality because, with the same production system, higher yields can be achieved on better land.
Therefore regions with good quality land, that are often already today important agricultural production areas (e.g. PL03 or R003), can in future also become important biomass production areas. Also, the biomass potential in such regions can further increase as more areas of agricultural land can become available by intensification and rationalization of agriculture.

Future developments on land use, cost and productivity levels in the CEEC are difficult to predict. Some expectations can be extrapolated from the experiences that were made in WEC, like a rationalization of agriculture in the EU and increases of land prices and labour costs. To deal with these uncertainties and to be able to identify and analyse the factors with major impact on biomass potentials, different scenarios were formulated of which 

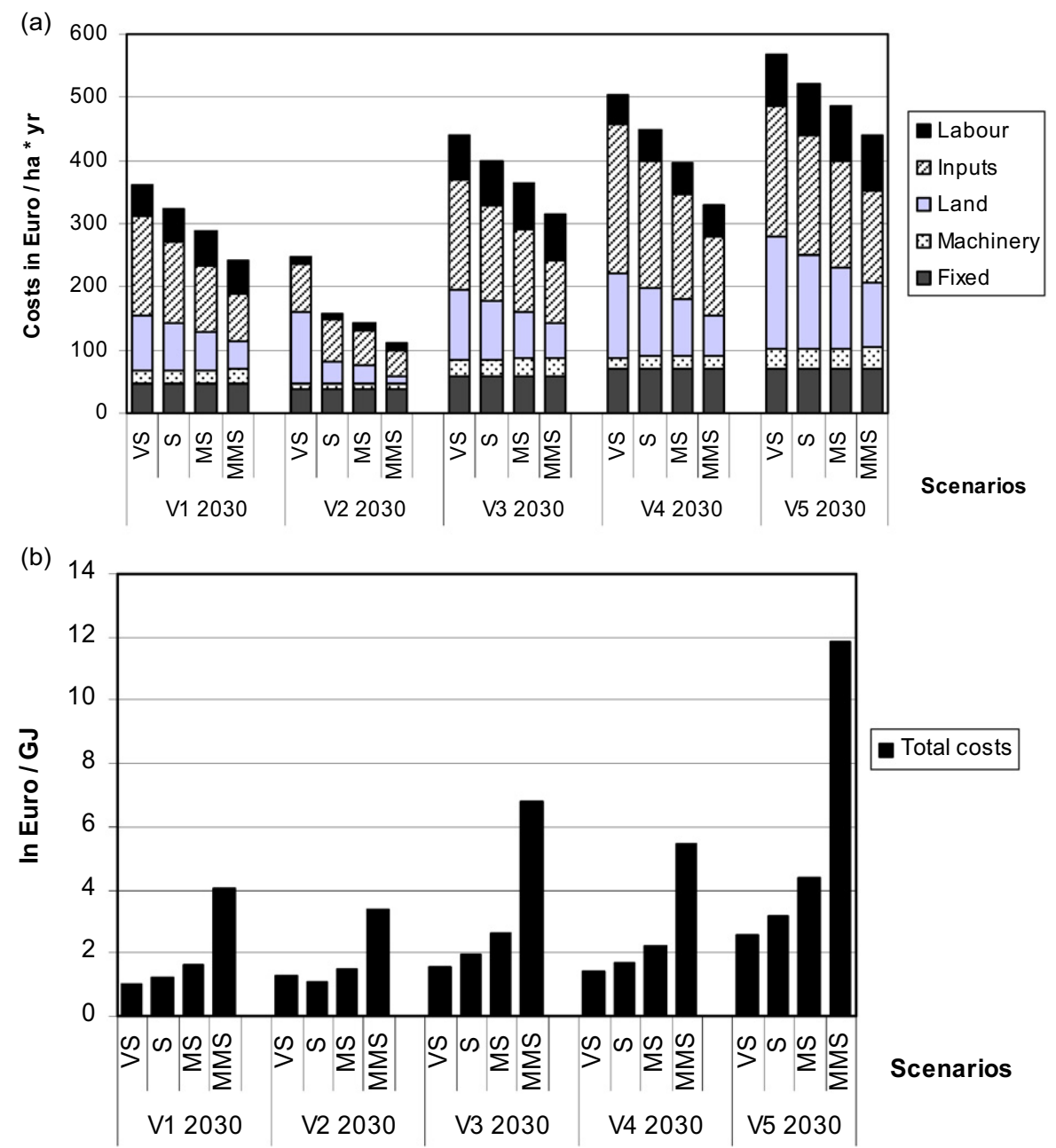

Fig. 12. (a) Total production costs, differentiated to cost items, in Poland for willow production in $€ /$ ha/yr for different scenarios and land suitability types. (b) Total production costs for willow in Poland in $€ /$ GJ HHV for different scenarios and land suitability types. Total production costs for willow in Poland based on $\mathrm{HHV}=18.4 \mathrm{GJ} / \mathrm{t}$ DM. Table 5 provides information about yield levels for willow in Poland for different land suitability types.

some extrapolate to extreme situations. This is especially true for the V1 scenario, which assumes full rationalization and the application of highly advanced and efficient agriculture in all CEEC. Due to several constraints the realization of such a scenario is hardly to be expected [57]. The same is true for scenario V5, which assumes that ecological agriculture will prevail in the EU. Presently organic agriculture has a share of about 3.5\% (5.6 million ha) in the EU 25 and only slight increases of this area are recorded in the WEC [62]. Scenario V2, which assumes maintenance of status quo with low productivity levels, is unlikely, too. We expect scenario V3, which assumes the full implementation of CAP reforms and agricultural production systems in CEEC, which develop towards the standards presently applied in WEC, as the most realistic scenario. Although some of the scenarios appear extreme, they helped to generate results from which important conclusions can be drawn.

The biomass potential in the CEEC is dominated by the potential from energy crops and therefore strongly depends on the amount of land that is available for their production. The availability of land for the production of energy crops depends on the land demand for food production. Policy, and in particular agricultural and trade policy, clearly has a strong influence on the demand and availability of land for food and biomass production. This is shown by the example of V1 scenario.

Future agricultural production in CEEC will rationalize. Therefore in the near future the amount of land needed for food production will significantly decrease, as has been shown in the scenarios V1, V3 and V4, which employ advanced agricultural production methods. The results of the analysis done here do not only show the high biomass potentials in the CEEC, but also the possibilities for production alternatives on the large agricultural areas that are likely to become available in the CEEC in the near future due to ongoing changes in agricultural production and production methods in those countries.

The results of the V5 scenario showed a conflict between the extension of ecological agriculture and large-scale biomass production. Reasons are the lower yields that are produced with ecological production methods, which 
lead to a higher demand of land for the production of food and fodder crops. This results in lower availability of land for energy crops, higher land use and consequently higher biomass production costs. A support of productive agricultural management systems, with the optimal use of agricultural inputs, modern varieties and efficient technologies, will also support the options of large-scale biomass production.

Biomass can be produced at lower costs in CEEC than in WEC. Bulk of the biomass in CEEC could be produced at costs lower than $2 € /$ GJ and therefore become available at lower costs than fossil oil. High potentials for bio-energy production and its competitiveness with bio-energy produced in WEC or fossil fuels indicate a significant biomass/ bio-fuel export potential for CEEC.

The costs for biomass production depend on the kind of energy crop chosen. Perennial lignocellulosic biomass crops have - in the order of willow, poplar, miscanthus - the lowest biomass production costs, followed by sugar beet and rapeseed. Main cost components of energy crop production are labour, land use and input costs. The production costs of perennial crops could significantly be decreased when better and cost efficient methods for establishment were developed. Because little experience with the production of perennial crops, especially miscanthus, have been made, a decrease of production costs can be expected by the establishment of pilot projects or large-scale plantations.

The production costs for willow and sugar beet range in the order of $200-550$ and $700-1200 € / \mathrm{ha} / \mathrm{yr}$, respectively. This indicates that low subsidies levels can easily support energy crops in the transition phase.

The comparison of different energy crops under different scenarios showed clearly that the production of perennial lignocellulosic crop is to be given preference when high biomass potentials, low biomass production costs and environmental benign production methods are to be combined. The production of perennial crops adds ecological value to agricultural areas because of their low demands for inputs (especially fertilizer and pesticides), their contribution to biodiversity, their positive impacts on soil fertility and carbon sequestration and their potential to avoid erosion and nutrient leaching $[65,66]$. Perennial crops have manifold characteristics that make them suitable for the establishment of multiple land use systems that deliver ecological (e.g. enhancement of biodiversity) or other services like the cleaning of wastewater or soils. Producing biomass in multiple land use systems contributes to the reduction of biomass production costs and to more efficient land use.

Although there is a high potential for the production of sugar beet and rape seed, too, it has to be seen that these crops have higher demands towards land quality, require high to very high input intensities (especially pesticides) and can lead to soil erosion.

The bulk of the biomass potential (83-94\%, depending on scenario chosen) comes from energy crops. To realize the high biomass production potential large areas of land, in the most extreme case, i.e. up to $78 \%$ of the current agricultural area or up to $43 \%$ of the total land area, could be used for the production of energy crops, while at the same time food demand is met and forest and nature areas are preserved. The introduction of these alternative crops and the development of new markets will have major socioeconomic implications for the CEEC with positive effects on employment options and the development of the agricultural sector and rural areas.

The potential analysis showed that, under a scenario with intensive, advanced agricultural production methods and optimal land allocation within CEEC, nearly $12 \mathrm{EJ}$ could be produced from biomass in the CEEC. In most CEEC, the production potentials are larger than the current energy use in the more favourable scenarios (such as V1). Combined with the low cost levels, this gives CEEC major export opportunities for the European and perhaps global market.

\section{Acknowledgements}

This study was done within the project VIEWLS (Clear VIEWS on Clean Fuels (NNES-2001-619)), which was financed by EC DG-TREN.

Data and information on CEEC were supplied by: Magdalena Rogulska, Marzena Rutkowska-Filipczak, Grzegorz Kunikowski (EC BREC/IBMER, Warsaw, Poland); Ádám Ragoncza and Pál Pecnik (Hungarian Institute of Agricultural Engineering (HIAE), Gödöllö, Hungary); Gheorge Valentin Roman, lenuta Iuliana Bucata (University of Agronomic Sciences and Veterinary Medicine Bucharest, Faculty of Agriculture, Romania); Jan Weger, Kamila Havlíčková (Silva Tarouca Research Institute for Landscape and Ornamental Gardening, Department of Phytoenergy, Průhonice, the Czech Republic).

\section{References}

[1] Fischer G, van Velthuizen H, Prieler S. Biomass energy from agricultural crops and plantation forestry: results and policy implications for North, Central and Eastern Europe. In: Proceedings of the conference on system aspects of greenhouse effects versus sustainable rural development: biomass, biofuels and fuel cells. IIASA, Warsaw, 2001.

[2] Faaij A. Bio-energy in Europe: changing technology choices. Energy Policy 2006;34:322-42.

[3] Faaij A, Minnesma M, Wieczorek AJ. International debate on international bio-energy trade. Report 2GAVE03.06. Amsterdam: Universiteit Utrecht, Vrije Universiteit Amsterdam, Industrial Transformation, 2003.

[4] DG Agriculture, EC. The Common Agricultural Policy - a policy evolving with the times, 2004. 〈http://europa.eu.int/comm/agriculture/publi/capleaflet/cap_en.htm $\rangle$.

[5] S. Baum, Frohberg K, et al., The future of rural areas in the CEE new member states. Halle (Saale): Institut für Agrarentwicklung in Mittelund Osteuropa; 2004.

[6] EUROSTAT. Statistical yield, production and area data for food crops for years 1995-2000 on Nuts-3 region level. EUROSTAT (Statistical Office of the European Union), 2003. 
〈http://epp.eurostat.cec.eu.int/portal/page?_pageid $=1090,1 \&$ dad $=$ portal\&_schema $=$ PORTAL $\rangle$.

[7] Lewandowski IM, van Hooijdonk A, Weger J, Havlickova K, van Dam J, Faaij A.P.C. The potential biomass for energy production in the Czech Republic. Biomass and Bioenergy 2006;30(5):405-21.

[8] Roman GV. Resources of energetic biomass on Romania's territory. In: Proceedings of the first world conference on biomass for energy and industry, vol. 1. Sevilla: James \& James Science Publishers Ltd.; 2000. p. 365-6.

[9] Fenyvesi L, Pecznik P. Potential use of renewable energy sources in Hungary. In: Proceedings of the first world conference on biomass for energy and industry, vol. 1. Sevilla: James \& James Science Publishers Ltd.; 2000. p. 253-5.

[10] MZP Ministerstvo životního prostředí České republiky. An alternative scenario of the State Energy Policy. Prague: Czech Ministry of Environment; 2003.

[11] Rogulska M, Oniszk-Poplawska M, Pisarek M, Wisniewski G. In: OECD, editor. Seminar on bioenergy and agriculture, Vienna, 2002.

[12] NOVEM. Draft report: the potential for energy from biomass, project no. 351196/1160. Utrecht: NOVEM; 1997.

[13] Fischer G, van Velthuizen H, Prieler S. Biomass potentials of miscanthus, willow and poplar. Biomass and Bioenergy 2004;28:119-32.

[14] Hoogwijk M. On the global and regional potential of renewable energy sources. Utrecht: Department for Science, Technology and Society, Copernicus Institute, University Utrecht; 2004.

[15] Smeets E, Faaij A, Lewandowski I. A quick scan of global bioenergy potentials to 2050. Part A: review of existing data and studies and the development of a bottom-up methodology. Utrecht: Department for Science, Technology and Society, Copernicus Institute, University Utrecht; 2004

[16] Weger J, Jiránek J. The potential and utilisation of biomass in the Czech Republic. In: Proceedings of the international conference biomass for energy and industry, Wurzburg, Germany, 1998. p. $1002-5$.

[17] EUROSTAT. Introduction to NUTS and statistical regions of Europe. EUROSTAT (Statistical Office of the European Union), 2002.

[18] Smeets E, Faaij A, Lewandowski I. A quick scan of global bioenergy potentials to 2050. Part B: regional bioenergy potential and an assessment of underlying variables. Utrecht: Department for Science, Technology and Society, Copernicus Institute, Universikty Utrecht; 2004.

[19] EUROSTAT (Statistical Office of the European Union). Tables XACROPS, XDarea, Xaanimal, XAGT1, Regional statistics Central European Candidate Countries Agriculture, April 2003.

[20] Weger J. Research Institute of Ornamental Gardening (RILOG), Pruhonice, Czech Republic, 2004.

[21] Rogulska M, Kunikowski G. Institute for Building, Mechanisation and Electrification of Agriculture (EC-BREC), Warsaw, Poland, 2004.

[22] Roman GV. University of Agronomic Sciences and Veterinary Medicine in Bucharest, Romania, 2004.

[23] Raconczga A, Pecznik P. Hungarian Institute of Agricultural Engineering, Budapest, Hungary, 2004.

[24] Boedeker G. FAO projections to 2015 and 2030 for individual Central and Eastern European Countries. Rome: Global Perspective Studies Unit (ESDG), FAO of the United Nations; 2003.

[25] Kangas K, Baudin A. Modelling of projections of forest products demand, supply and trade in Europe, ECE/TIM/DP/30 (final edit). Geneva: UN-ECE, Timber Section; 2004.

[26] Timber Section U.N.-E.C.E. Country profiles, development of European Forest resources 1950-2000 (draft version), ECE/TIM/ DP/DT. Geneva: United Nations Economic Commission for Europe; 2004.

[27] Schelhaas MJ, van Brusselen J, Pussinen A, Pesonen E, Schuck A, Nabuurs G, et al. Outlook for the development of European Forest Resources, a study prepared by the European Forest Sector Outlook
Study (EFSOS). Geneva: Timber Section United Nations Economic Commission for Europe (UNECE) and Food and Agricultural Organization (FA); 2004.

[28] DG Agriculture, European Commission. Prospects for agricultural markets in the candidate countries from Central and Eastern Europe. Annual report, European Commission, Brussels, 2001.

[29] Bouwman FA, van der Hoek KW, Eickhout B, Soenario I. Exploring changes in world ruminant production systems. RIVM, Bilthoven, Netherlands; 2003.

[30] RIVM. The IMAGE 2.2 implementation of the SRES scenarios, a comprehensive analysis of emissions, climate change and impacts in the 21 st century. RIVM, Bilthoven, Netherlands, 2001.

[31] Fischer G. Personal communication: data received on $50 \times 50 \mathrm{~km}$ grid cell for CEEC based on AEZ methodology. IIASA, Laxenburg, Austria, 2004.

[32] IIASA. Global agro-ecological assessment for agriculture in the 21st century. Land and water digital media series, number 21, CD-rom. FAO, editor, Rome, 2002.

[33] Plant Production and Protection Division FAO, ECOCROP database online, FAO, Rome, 2000. 〈http://ecocrop.fao.org/ $\rangle$.

[34] Poostchi I. Crop production in Europe and the CIS. Henley-on Thames, UK, 1997. ISBN: 1874539049.

[35] FAOSTAT, Agricultural data, Statistical division Food and Agricultural Organizations; 2004, 〈http://apps.fao.org/page/collections? subset $=$ agriculture $>$.

[36] Hamnett R. Country pasture/forage resource profile Bulgaria. Rome: FAO; 2003.

[37] Královec J. Country pasture/forage resource profile Czech Republic. Rome: FAO; 2003.

[38] Selge A. FAO country pasture/resource profile Estonia. Rome: FAO; 2003.

[39] Breymeyer AI. Ecosystems of the world 17A, Managed grasslands, regional studies. Elsevier; 1990.

[40] Lee J. Forages. Livestock Production Science 1998;19:13-46.

[41] Géza N. Yield potential of Hungarian grasslands. Agricultural University of Debrecen, Hungary 1995;31:275-84.

[42] Bouwman L. Map grass consumption all grasslands in 1995 for CEEC. RIVM, Bilthoven, Netherlands, 2004.

[43] Siebert S, Döll P, Hoogeveen J. Global map of irrigated areas version 2.1. Center for Environmental Systems Research, University of Kassel, Germany and FAO, Rome, Italy, 2002.

[44] UNECE. Forest resources of Europe, CIS, North America, Australia, Japan and New Zealand (industrialized temperate/boreal countries), UN-ECE/FAO contribution to the Global Forest Resources Assessment 2000. Timber and forest study papers, no. 17, New York and Geneva: United Nations Publication; 2000.

[45] UNECE. European timber trends and prospects: into the $21 \mathrm{st}$ century ECE/TIM/SP/11. Geneva: UNECE Timber Section and FAO; 1996

[46] DG Agriculture, EC. Agriculture in the European Union, statistical and economic information 2003, Prices and production costs, par. 3.3.8 Market value of agricultural land (parcels), Brussels, 2003. 〈http:// europa.eu.int/comm/agriculture/agrista/2003/table_en/338.pdf $\rangle$.

[47] Estonian Land Board, Latvian State Land Service, Lithuanian State Land Cadastre and Register. Review of Baltic States real estate market 2002, 2003. 〈http://www.kada.lt/ntr/stat/review2003/〉.

[48] Prosterman R, Rolfes L. Agricultural land markets in Lithuania, Poland and Romania: implications for accession to the European Union. Washington, USA: Rural Development Institute; 2003.

[49] Trivelli C. Land markets and land prices in the Central European Free Trade Agreement Countries. Rome: FAO Sustainable Development Department, Land Tenure; 1997.

[50] Dumitru M. Country case studies on integrating land issues into the broader development agenda. In: Bucharest A, editor. EU delegation, Proceedings of regional workshop on land issues in Europe and the CIS, Worldbank, Budapest, April 2002.

[51] Kopeva D. Country case study: land markets in Bulgaria. In: Sofia B, editor. Institute for Market Economics (IME). Proceedings of the 
World Bank regional workshop on land policy issues: Central Europe and CIS, Budapest, Hungary, 3-6 April 2002.

[52] Burger A. Land valuation and land rents in Hungary. Land use Policy 1998;15:191-201.

[53] ILO, International Labour Organization. LABORSTA, employment, unemployment, wages and hours of work. 2000.

[54] Raconczga A. Personal communication about production costs for agricultural crops in Hungary. Budapest, Hungary: Hungarian Institute of Agricultural Engineering (HIAE); 2004.

[55] Kaltschmitt M, Reinhardt GA. Nachwachsende Energieträger. Grundlagen, Verfahren, ökologische Bilanzierung. Vieweg, Braunschweig, Wiesbaden, 1997.

[56] Fischer G, van Velthuizen H, Nachtergaele FO. Global agroecological zones assessment: methodology and results. Interim report. IIASA, Laxenburg, Austria, 2000.

[57] FAO. World agriculture: towards 2015/2030. Rome: Earthscan Publications; 2003.

[58] van Dam J, Faaij A, Lewandowski I. Methodology and data requirement for regional biomass potential assessment in the CEEC, VIEWLS report. Utrecht: Department of Science, Technology and Society, Copernicus Institute, University Utrecht; 2005.

[59] Quade J. Faustzahlen für Landwirtschaft und Gartenbau. Verlagsunion Agrar, Landwirtschaftsverlag GmbH, Muenster-Hiltrup, 1993.

[60] Kauter D, Lewandowski I, Claupein W. Quantity and quality of harvestable biomass from Populus short rotation coppice for solid fuel use - a review of the physiological basis and management influences. Biomass and Bioenergy 2003;24:411-27.

[61] Smeets EMW, Faaij APC, Lewandowski IM, Turkenburg WC. A quickscan of global bio-energy potentials to 2050. Progress in Energy and Combustion Science 2006;1(33):56-106. (NWS-E-2006-202).
[62] Organic-Europe. Organic farming in Europe. Statistics in focus. Agriculture and Fisheries 13/2005; 2005. 〈http://www.organic-europe. net/europe_eu/statistics.asp $>2005$.

[63] DG TREN, European Commission. Final energy consumption in acceding and energy countries Table 2.6. In: Tren DG, editor. Statistical Pocket book, energy and transport in figures. Brussels, 2003.

[64] European Commission, Directive 2003/30/EC of 8 May 2003 on the promotion of the use of biofuels or other renewable fuels for transport, Brussels, 2003.

[65] EEA Report No. 7/2006. How much bio energy can produce Europe without harming the environment? European Environment Agency, Copenhagen, 2006, 67p.

[66] Hope, A, Johnson, B. English nature. Discussion paper on biofuels. Terrestrial Wildlife Team, 2003.

[67] Falkenburg D, Thraen D. Cost calculations selected model regions in Poland, Romania, Hungary and Czech Republic. Institut für Energetik und Umwelt, Leipzig; 2004.

[68] World Bank. World Bank development Indicators on CD-Rom, pump price for diesel fuel. New York: World Bank; 2002.

[69] Zdenek Abrham a kolektiv I. Doporucené technoloogické postupy pestování okopanin a pícnin a jejich ekonomika. Prague: Institut výchovy a vzdelávání Ministerstva zemedelstvie CR v Praze; 1998.

[70] Lewandowski I. Personal communication about costs for rapeseed production in different production systems. Utrecht University, the Netherlands, 2004.

[71] Kaltschmitt M, Reinhardt G. Nachwachsende Energieträger: Grundlagen, Verfahren, ökologische bilanzierung, 1997.

[72] Kunikowski G, Rogulska M. Data received from EC-BREC\& Hakan Rosenqvist calculations, based on Swedish experiences with large-scale willow cultivation. Poland: EC Baltic Renewable Energy Centre; 2004. 